Article

\title{
Investigating the Relationship between Human Activity and the Urban Heat Island Effect in Melbourne and Four Other International Cities Impacted by COVID-19
}

\author{
Cheuk Yin Wai ${ }^{1}\left(\mathbb{D}\right.$, Nitin Muttil $^{1,2} \mathbb{D}$, Muhammad Atiq Ur Rehman Tariq ${ }^{1,2} \mathbb{D}$, Prudvireddy Paresi ${ }^{3}$, \\ Raphael Chukwuka Nnachi ${ }^{4}$ (D) and Anne W. M. Ng ${ }^{5, *(D)}$
}

check for updates

Citation: Wai, C.Y.; Muttil, N.; Tariq, M.A.U.R.; Paresi, P.; Nnachi, R.C.; Ng, A.W.M. Investigating the

Relationship between Human

Activity and the Urban Heat Island Effect in Melbourne and Four Other International Cities Impacted by COVID-19. Sustainability 2022, 14, 378. https://doi.org/10.3390/ su14010378

Academic Editors:

Salman Shooshtarian and Inji Kenawy

Received: 24 October 2021

Accepted: 26 December 2021

Published: 30 December 2021

Publisher's Note: MDPI stays neutral with regard to jurisdictional claims in published maps and institutional affiliations.

Copyright: (C) 2021 by the authors. Licensee MDPI, Basel, Switzerland. This article is an open access article distributed under the terms and conditions of the Creative Commons Attribution (CC BY) license (https:// creativecommons.org/licenses/by/ $4.0 /)$.
1 College of Engineering and Science, Victoria University, Melbourne, VIC 8001, Australia; cheuk.wai@live.vu.edu.au (C.Y.W.); nitin.muttil@vu.edu.au (N.M.); atiq.tariq@yahoo.com (M.A.U.R.T.)

2 Institute for Sustainable Industries \& Liveable Cities, Victoria University, Melbourne, VIC 8001, Australia

3 School of Engineering, Information Technology and Physical Sciences, Federation University, Ballarat, VIC 3350, Australia; pprudvi108@gmail.com

4 Faculty of Biological Sciences, Alex Ekwueme Federal University Ndufu Alike Ikwo, Abakaliki P.M.B 1010, Nigeria; nnachi.raphael@funai.edu.ng

5 College of Engineering, Information Technology and Environment, Charles Darwin University, Ellengowan Drive, Brinkin, NT 0810, Australia

* Correspondence: Anne.Ng@cdu.edu.au

\begin{abstract}
Climate change is one of the biggest challenges of our times, even before the onset of the Coronavirus (COVID-19) pandemic. One of the main contributors to climate change is greenhouse gas (GHG) emissions, which are mostly caused by human activities such as the burning of fossil fuels. As the lockdown due to the pandemic has minimised human activity in major cities, GHG emissions have been reduced. This, in turn, is expected to lead to a reduction in the urban heat island (UHI) effect in the cities. The aim of this paper is to understand the relationship between human activity and the UHI intensity and to provide recommendations towards developing a sustainable approach to minimise the UHI effect and improve urban resilience. In this study, historical records of the monthly mean of daily maximum surface air temperatures collected from official weather stations in Melbourne, New York City, Tokyo, Dublin, and Oslo were used to estimate the UHI intensity in these cities. The results showed that factors such as global climate and geographic features could dominate the overall temperature. However, a direct relationship between COVID-19 lockdown timelines and the UHI intensity was observed, which suggests that a reduction in human activity can diminish the UHI intensity. As lockdowns due to COVID-19 are only temporary events, this study also provides recommendations to urban planners towards long-term measures to mitigate the UHI effect, which can be implemented when human activity returns to normal.
\end{abstract}

Keywords: urban heat island effect; COVID-19; pandemic; green infrastructure; livability

\section{Introduction}

Following the declaration of a global pandemic by the World Health Organization (WHO) on 11 March 2020, many countries had to tighten their borders and apply lockdown measures to limit the spread of COVID-19 and reduce the deaths [1,2]. By November 2020, there had been 5.3 million confirmed cases and 1,305,164 deaths recorded globally [3].

Governments around the world were struggling to stop the spread of the virus and began to introduce strict policies that limited human contacts and activities to prevent further transmission of the virus [4]. Among all the cities worldwide, Melbourne, Australia, has had the longest and strictest lockdown measures so far, with travel restrictions and a nighttime curfew in place [5]. Public transport usage decreased by more than $80 \%$ during the lockdown [6]. The Australian Energy Market Operator (AEMO) reported that the energy demand in Victoria reduced by $8 \%$ (approximately 400 Megawatts) during morning peak 
time in April 2020 [7]. Although the pandemic has caused devastating impacts, research has suggested there have been positive impacts on the environment due to the reduction in greenhouse gases (GHG) and air pollution levels caused by human activity and outdoor mobility. Reported by the Bureau of Meteorology (BoM) and Commonwealth Scientific and Industrial Research Organisation (CSIRO) [8], the carbon dioxide $\left(\mathrm{CO}_{2}\right)$ emissions in Australia declined by $8 \%$ in the first three months of 2020 compared with the same period in 2019. The Economic Times [9] also reported that the global carbon emissions had declined by 17\% between January and April due to the COVID-19 lockdown measures.

Aside from carbon emissions, the overall air quality had improved in different countries after the implementation of the lockdown. Several studies demonstrate a significant reduction in Particulate Matter (PM), Sulphur Dioxide $\left(\mathrm{SO}_{2}\right)$, Nitrogen Oxide (NO), and Nitrogen Dioxide $\left(\mathrm{NO}_{2}\right)$ concentration during the lockdown [10-15]. The exception to this is Ozone $\left(\mathrm{O}_{3}\right)$ levels, which increased during the lockdown [16-18]. All these COVID-19 related studies investigated energy consumption and emissions in relation to human activities such as transportation and industrial activities. While these factors have directly contributed to the urban heat island (UHI) effect, not many studies have investigated the change in the UHI effect due to the reduction in human activity in major cities due to lockdown restrictions.

The pandemic reduced human activity to extraordinarily low levels, which created a unique opportunity to investigate the influence of human activity on the UHI effect (factors affecting UHI are illustrated in Figure 1). Having one of the strictest and longest periods of restrictions to human activity, Melbourne was taken as the benchmark to compare and analyse other international cities with shorter periods of lockdown. This paper provides an understanding of the relationship between human activity and UHI intensity. It also provides recommendations on mitigation of the UHI effect in urban areas and for developing a sustainable approach to improve urban resilience, which in turn can be implemented in other major cities worldwide.

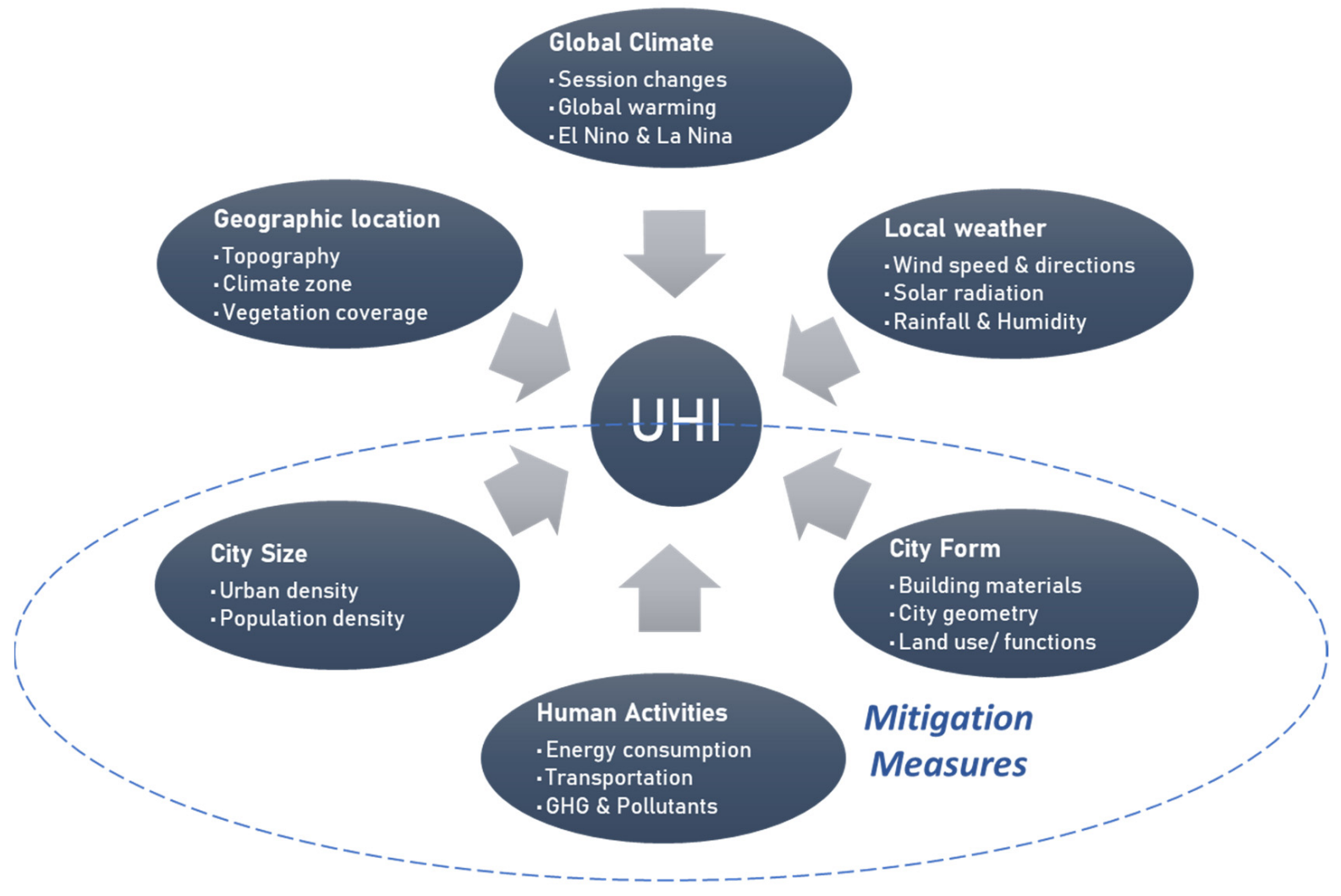

Figure 1. Factors that cause Urban Heat Island Effect. 


\section{The Urban Heat Island (UHI) Effect}

The UHI effect is the phenomenon whereby the temperature in the city center is higher than in the rural surrounding [19,20]. A study by Imhoff in 2009 [21] assessed 38 of the most populous cities in the United States showed that the annual average temperature in urban areas is $2.9^{\circ} \mathrm{C}$ warmer than non-urban areas, except cities located in biomes with arid and semi-arid climates. This is because cities in semi-arid and arid regions might experience urban cool islands (UCI) during the daytime when the surface temperatures of rural areas are hotter than urban areas (when the UCI is relatively weak in intensity) [22]. The effect of climate zones and seasonal effects on UHI was also analysed by Wu, Zhang, and Zang in 2019 [23] and pointed out that seasonal changes also affect the UHI, where $\mathrm{UHI}$ only exists in spring and summer with no significant effect in autumn and winter.

\subsection{Causes of Urban Heat Island Effect}

Local weather is one of the factors that is associated with the UHI effect. After investigating the mean sea level pressure over a 19-year period from 1973 to 1991, Morris and Simmonds [24] found that the UHI magnitude in Melbourne was associated with anomalous anticyclone conditions. Another study conducted by Morris, Simmonds, and Plummer [25], which analysed the daily wind speed and cloud amount over a 20-year period from 1972 to 1991, showed that the UHI is related to turbulent and radiative exchanges.

Regardless of the natural factors, the main cause of UHI is increasing urbanization and rapid population growth. In urban areas, high-rise buildings and mass transportation systems were built to accommodate the population, with extensive use of concrete, steel, and glass, which absorb solar radiation [26]. While human activities for commercial and industrial purposes consume huge amounts of electrical power and fossil fuels, the number of carbon emissions and pollutants released into the atmosphere by the buildings trap emitted heat [27].

Factors that contribute to the UHI effect are summarised and illustrated in Figure 1. The figure also shows that factors caused by atmospheric and natural environments are mostly uncontrollable, but factors created by various human activities are relatively easy to control. In addition, mitigation measurements mainly focus on three areas, namely human activity, city form, and city size [28]. Mitigation measures related to human activities include reduction in transportation, energy consumption, greenhouse gases (GHG), and pollutants. Mitigation measures related to city form include building materials, city geometry, and land use/land function. The most effective solution to reduce UHI would be the reduction of city size; however, this is not a possible solution for most cities as this would slow down the economic growth.

\subsection{The Importance of Evaluating the Urban Heat Island Effect}

Before the world was threatened by the COVID-19 outbreak, climate change was one of the major concerns in Australia. In 2019, the continent had experienced the hottest and driest year on record, and extreme heat events such as heatwaves, drought, and wildfires had catastrophic consequences across the nation [8]. As reported by the National Ocean and Atmospheric Administration (NOAA) [29], the year 2020 was the second warmest year in the 141-year record, with a $+9.8^{\circ} \mathrm{C}$ global land and ocean surface temperature anomaly. With the prevailing global warming in 2020, extreme heat events are expected to increase in terms of frequency, duration, and magnitude [8,30].

Extreme heat events proved to be one of the greatest hazards to human wellbeing that increase the mortality of people with pre-existing health problems, such as cardiovascular disease, respiratory allergies, and airway diseases [31,32]. As extreme high temperatures and high levels of air pollution are usually observed at the same time, it is believed that these two factors have a strong interaction [33]. As observed by Hansel, McCormack, and Kim [34], both extreme temperature and air pollutants are associated with higher respiratory morbidity in chronic obstructive pulmonary disease. A study by the NOAA showed that heat-related fatalities are higher than any other weather-related fatality on average in 
30-years [35]. The 2003 summer heatwave in Europe resulted in severe casualties across European countries, with more than 40,000 deaths due to excessive temperatures $[36,37]$. There were approximately 14,000 deaths in France and 2091 deaths in England as officially recorded by respective Health Authorities [38-40].

Studies have shown that the urban context is associated with heat-related deaths and mortality, which might significantly increase under extreme heat events [41,42]. A similar study conducted by Zhao et al. (2018) also shows that the UHI and heatwaves have significant synergistic effects in temperate climate regions with higher than $0.4{ }^{\circ} \mathrm{C}$ average UHI. Thus, they found that air conditioning energy use during heatwaves is a key contributor to UHI in those climate regions during the daytime [43]. Between 2004 and 2018, an annual average of 702 heat-related deaths was recorded in a large central metropolitan area in the United States, out of a total of 4402 deaths [44]. The UHI effect has a direct impact on human health by increasing the maximum air temperature to dangerous levels that could lead to heat-related illnesses and mortality. It also leads to indirect impacts by changing the living environment and human behaviors. These relationships are summarised in Figure 2 [45].

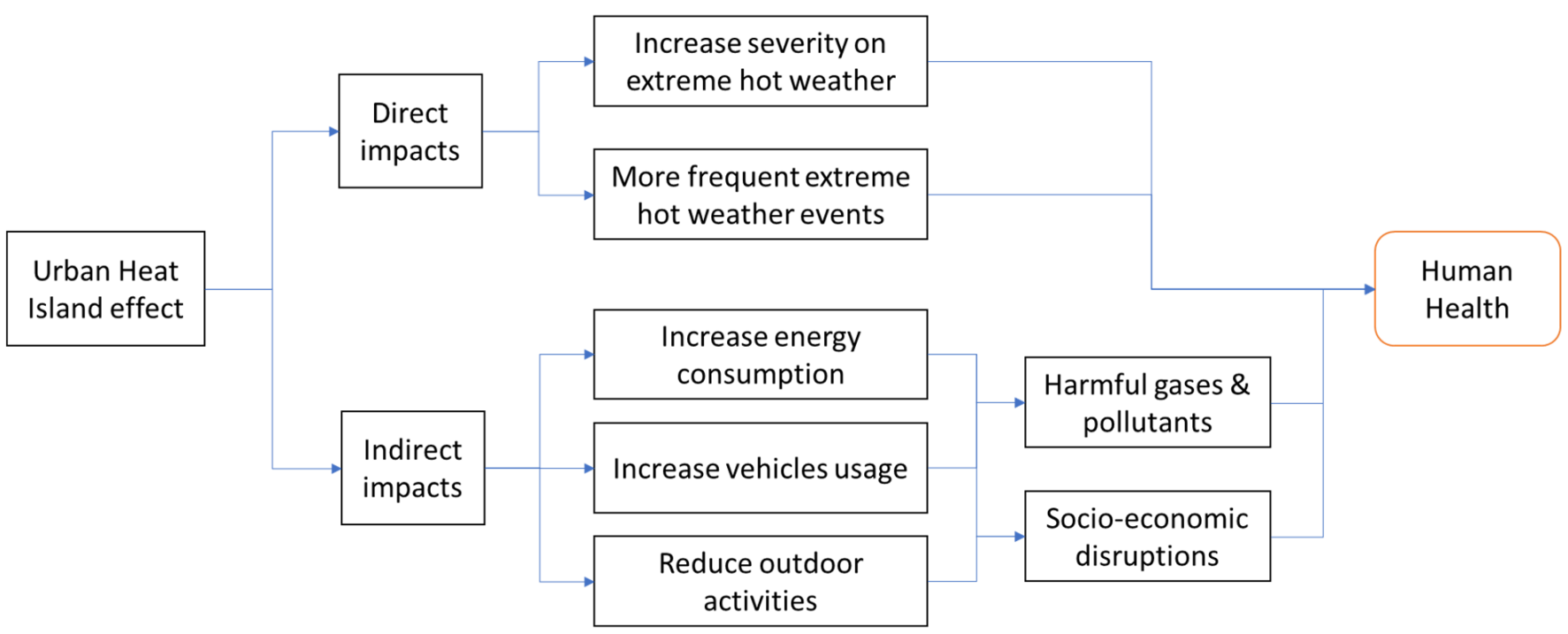

Figure 2. Direct and indirect impacts of Urban Heat Island effect on human health.

In the study by He et al. [46], they suggested that the surface air temperature has a stronger influence on the COVID-19 transmission pattern than the surface relative humidity. Extra cautions were recommended when operating the cooling centres in summer due to the risk of the spread of the virus into the air ventilation system [44]. Therefore, it can be expected that the COVID-19 outbreak will make it more challenging to save lives during extreme heat events in urban areas with high population density.

\section{Materials and Methodology}

The following sections will discuss the methodology of the study under consideration, the calculations to estimate the UHI intensity, and justification for data collection. Using the results from each study area's analysis provides a comprehensive summary of insights for the recommendations for future studies. 


\subsection{Study Area}

This paper's focus was on the change of UHI worldwide under the impact of the global pandemic, and the factors considered in the selection of international cities are as follows:

- Availability of sufficient historical data for estimating the UHI effect;

- Large population size and urban area to observe a significant change in human activities;

- The level of restriction on human activities due to COVID-19;

- The duration of lockdown that the city has experienced;

- Location in a coast area;

- Köppen climate classification of group $C$ and $D$ without dry season (letter code $\mathrm{f}$ ).

Based on the above considerations, Melbourne, Tokyo, New York City, Dublin, and Oslo were selected as case study cities in this paper. These are some of the most developed cities around the globe, with the highest level of urbanisation and population density in their country, where human activities were most impacted by the COVID-19. Table 1 summarises the location, population, land area, and Köppen climate classification for these cities.

Table 1. Information about the selected cities.

\begin{tabular}{|c|c|c|c|c|}
\hline City & $\begin{array}{l}\text { Geographical Location } \\
\text { (Latitude, Longitude) }\end{array}$ & $\begin{array}{l}\text { Population } \\
\text { (Thousands) }\end{array}$ & Land Area $\left(\mathbf{k m}^{2}\right)$ & Köppen Climate Classification \\
\hline Melbourne & $\begin{array}{c}\text { Costal Area } \\
\left(37.81^{\circ} \mathrm{S}, 144.96^{\circ} \mathrm{E}\right)\end{array}$ & 4963 & 9993 & oceanic climate $(\mathrm{Cfb})$ \\
\hline Tokyo & $\begin{array}{c}\text { Costal Area } \\
\left(35.68^{\circ} \mathrm{N}, 139.75^{\circ} \mathrm{E}\right)\end{array}$ & 35,600 & 13,555 & humid subtropical climate (Cfa) \\
\hline New York City & $\begin{array}{c}\text { Costal area } \\
\left(40.78^{\circ} \mathrm{N},-73.97^{\circ} \mathrm{E}\right)\end{array}$ & 8337 & 783.8 & $\begin{array}{l}\text { humid subtropical climate (Cfa); } \\
\text { humid continental climate (Dfa) }\end{array}$ \\
\hline Dublin & $\begin{array}{c}\text { Costal Area } \\
\left(53.35^{\circ} \mathrm{N},-6.27^{\circ} \mathrm{E}\right)\end{array}$ & 1111 & 317.5 & marine west coast climate (Cfb) \\
\hline Oslo & $\begin{array}{c}\text { Costal Area } \\
\left(59.91^{\circ} \mathrm{N}, 10.75^{\circ} \mathrm{E}\right)\end{array}$ & 693 & 426.4 & humid continental climate (Dfa) \\
\hline
\end{tabular}

\subsection{Estimate the UHI Intensity}

There are several methods used to analyse the UHI phenomenon depending on the objectives of the study. For example, the application of ECOTECT and Computational Fluid Dynamics (CFD) technology based on thermal and humidity index (THI) can provide a numerical simulation of urban thermal environment for future urban planning purposes [47].

UHI Intensity is a conventional method commonly used for quantifying the UHI phenomenon, which is calculated from the change in temperature between the urban temperature and rural temperature [48,49]. A negative value indicates an urban cool island (UCI), where the rural surroundings have a higher temperature than the urban area [50]. Depending on the nature of the study, the urban and rural temperature can use either the air temperature measured by ground-based sensor or land surface temperature (LST) recorded by aircraft or satellites $[51,52]$. The equation is shown as follow:

Equation (1): UHI intensity

$$
\text { UHI intensity }\left({ }^{\circ} \mathrm{C}\right): \Delta T=T_{U}-T_{R}
$$

According to the United States Environmental Protection Agency (USEPA) [51], a reasonable number of standard weather stations should be considered to improve accuracy and avoid bias when measuring temperatures for UHI study. The classification between an urban and rural weather station uses a combination of population density and urban settlement in relation to the city range measured from a reference station located in the Central Business District (CBD). As the classification varies between countries, for example, for the US, the Census Bureau has two types of urban area identifications. The classification 
and location of weather stations used in this report are mapped in Section 3.3, with brief details for each city [53]. The mean values of urban weather stations $\left(U_{i}\right)$ are the urban temperature $\left(T_{U}\right)$. Similarly, the mean values of rural weather stations $\left(R_{i}\right)$ are the rural temperature $\left(T_{R}\right)$, and the equations are shown as follow:

Equation (2): Average Urban Temperature

$$
\text { Average Urban Temperature }\left({ }^{\circ} \mathrm{C}\right): T_{U}=\frac{\sum T_{U i}}{\text { number of } U_{i}}
$$

Equation (3): Average Rural Temperature

$$
\text { Average Rural Temperature }\left({ }^{\circ} \mathrm{C}\right): T_{R}=\frac{\sum T_{R i}}{\text { number of } R_{i}}
$$

\subsection{Data Collection}

According to the USEPA, the air temperature and seasonal temperature patterns are more useful measurements in understanding the energy use and health risks associated with UHI [51]. Therefore, the daily maximum air temperature was collected to calculate the monthly average of UHI intensity. The data were retrieved from the historical climate database recorded by the existing official weather stations of the Bureau of Meteorology (BoM), Japan Meteorological Agency (JMA), National Weather Service (NWS), Met Éireann Forecast (MET), and Norwegian Climate Service Center (NCSC). Each weather station has an elevation, latitude, and longitude for the analysis of the exact location to understand the micro-climate that might affect the results [54-58].

The maps in Figures 3 and 4 were extracted from City Population [59]. Figure 3 presents the density of urban footprint measured in percentage, and Figure 4 illustrates the population density, which was based on the information from the Australian Bureau of Statistics (ABS) for Melbourne, United States Census Bureau (USCB) for New York City, National Statistics Center (NSC) for Tokyo, Central Statistics Office (CSO) for Dublin, and Statistisk Sentralbyrå (SSB) for Oslo [60-64]. For Melbourne, New York City, and Tokyo, which have a larger urban footprint, the urban weather stations (U) were considered within a $25 \mathrm{~km}$ range with a population density higher than 1000 people per $\mathrm{km}^{2}$. Rural weather stations (R) were at least $75 \mathrm{~km}$ away from the CBD, with less than 500 people per $\mathrm{km}^{2}$. For Dublin and Oslo, which have a smaller urban footprint, urban weather stations were considered within a $15 \mathrm{~km}$ range with a population density higher than 500 people per $\mathrm{km}^{2}$, whereas rural weather stations are at least $70 \mathrm{~km}$ away from the CBD with less than 50 people per $\mathrm{km}^{2}$. The details of the selected weather stations for each city are summarised in Tables A1-A5 under Appendix A.

The selected data range was focused on the coronavirus influences on the UHI due to human activities. The paper analysed the historical records from 2016 to 2020, which is sufficient to show the UHI intensity differences before and after the pandemic outbreak and made provisions for the analysis of the global climate trend. It was limited to the last five years due to the rapid rate of urbanisation that has turned many rural areas into urban areas in recent years. As different countries were influenced by COVID-19 on different dates, the mitigation measurements are dependent on countries; however, the details of the timeline and level of restrictions are further discussed in Section 4. 


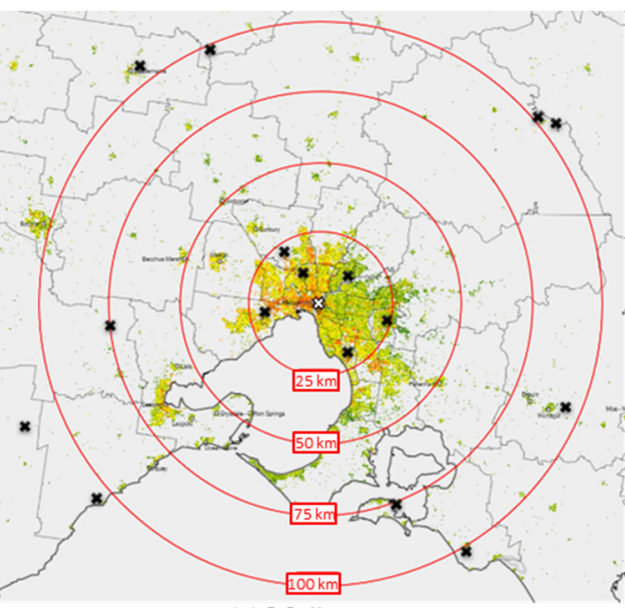

(a) Melbourne

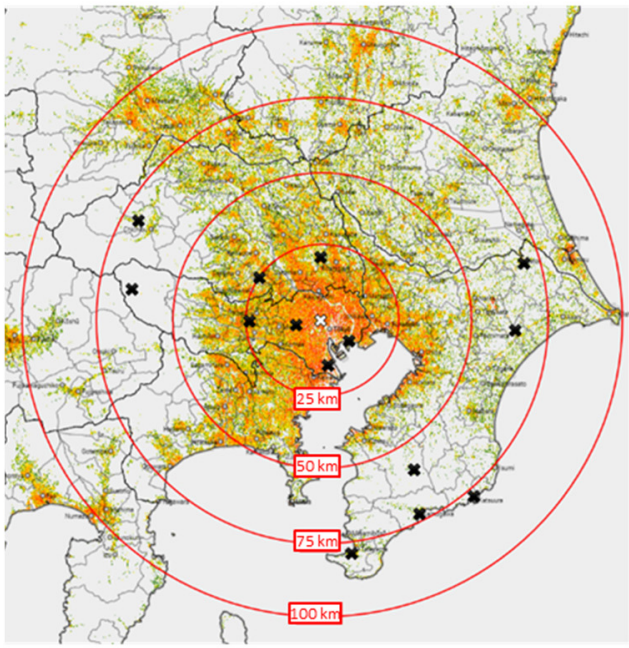

(c) Tokyo

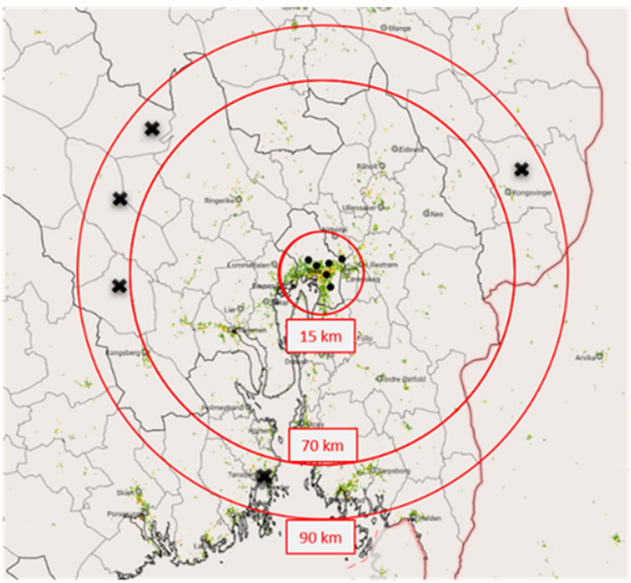

(e) Oslo

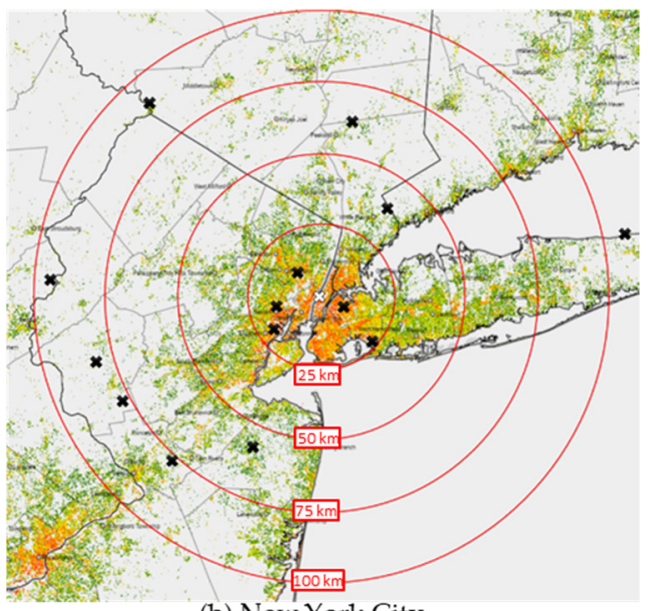

(b) New York City

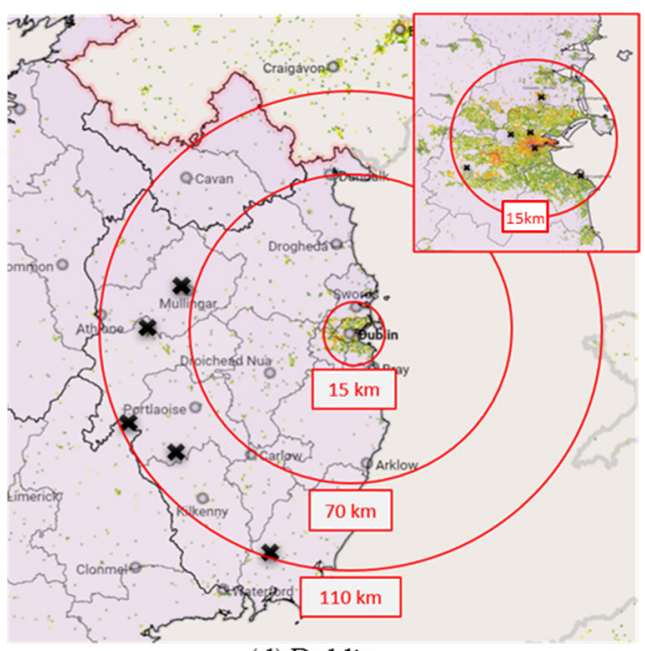

(d) Dublin

\section{Legend:}

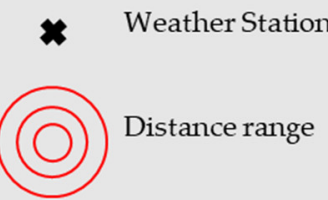

Global Urban Footprint scale (\%)

High

$100 \%$

ow

$0 \%$

Figure 3. Global Urban Footprint in the selected cities: (a) Melbourne, (b) New York City, (c) Tokyo, (d) Dublin, and (e) Oslo. The color scale represented the proportion of settlment areas in percentage. Areas in red or orange color are considered urban region with more than $50 \%$ of globa urban footprint, yellow color indicated the suburbs region, and green color indicated the rural area with less than $50 \%$ globa urban footprint. Urban weather stations are all within the most inner circle and the rest are the rural weather stations. 


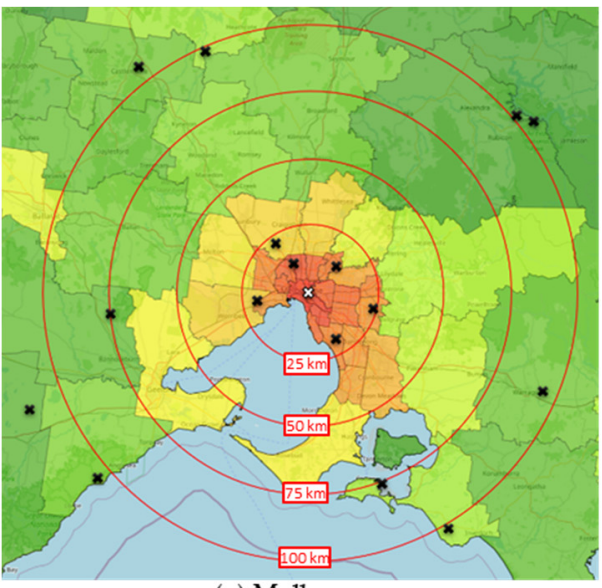

(a) Melbourne

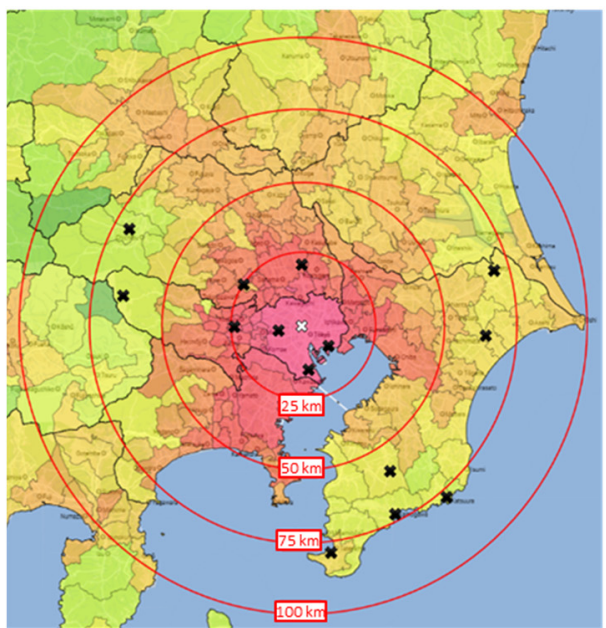

(c) Tokyo

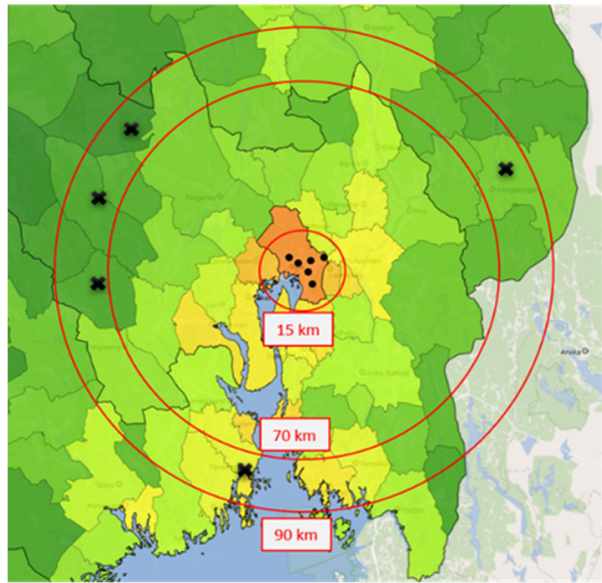

(e) Oslo

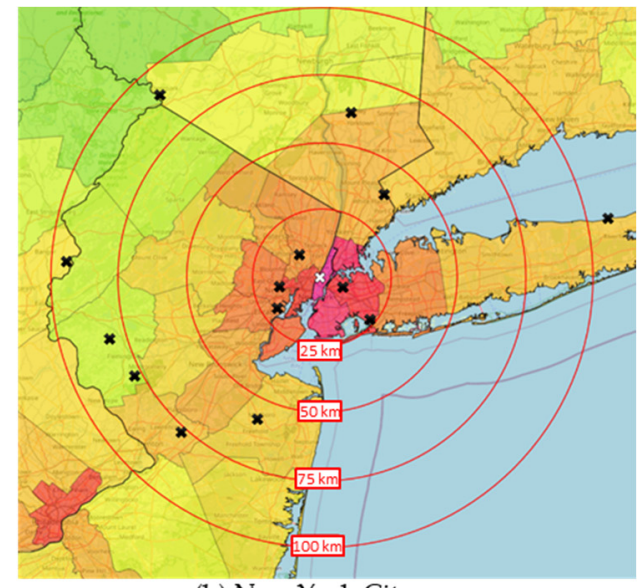

(b) New York City

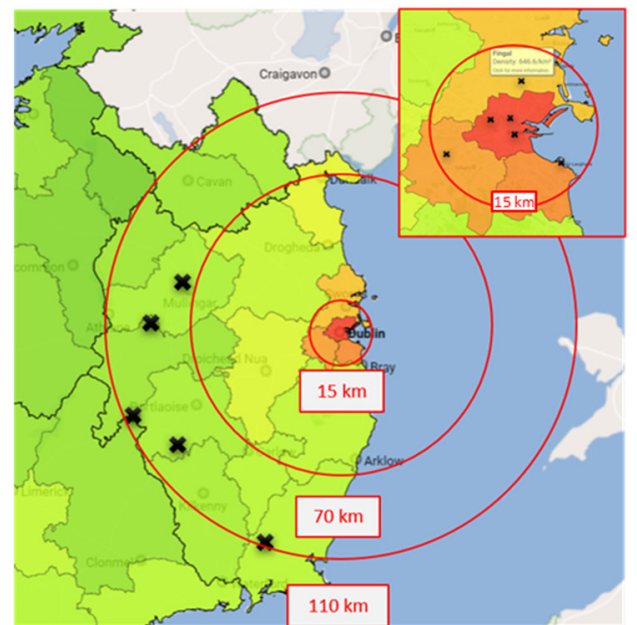

(d) Dublin

\section{Legend:}

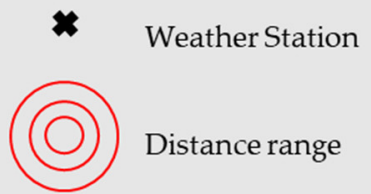

Population Density color scale (ppl/ $\mathrm{km}^{2}$ )

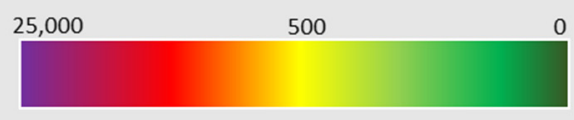

Figure 4. Population density in the selected cities: (a) Melbourne, (b) New York City, (c) Tokyo, (d) Dublin, and (e) Oslo. The color scale represented the population density in people per kilometer square. Areas with more than $1000 \mathrm{ppl} / \mathrm{km}^{2}$ should considered as urban region with spectrum from orange to purple; areas with population density between $500-1000 \mathrm{ppl} / \mathrm{km}^{2}$ are considered suburbs with yellow or orange color; and areas with less than $500 \mathrm{ppl} / \mathrm{km}^{2}$ are considered as rural areas. 


\section{Analysis of Results}

\subsection{Melbourne}

Figure 5 demonstrates the UHI intensity in Melbourne from 2016 to 2020. It shows a high UHI intensity that is usually experienced between June and September, which is the winter period in the southern hemisphere. In contrast, the UCI effect only occurred in the summer period between December and January.

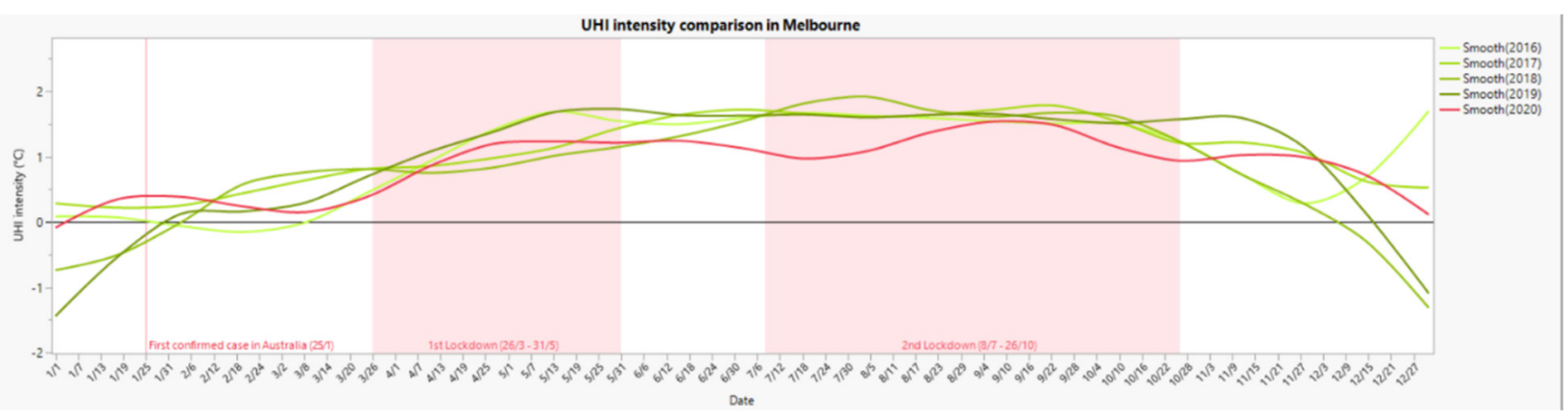

Figure 5. Melbourne UHI intensity analysis. The curves represented the UHI intensity patterns in last 5 years, and the red curve highlights the changes in 2020 with shaded regions that indicated the duration of lockdowns. Same format applies to rest of the figures.

In 2020, the UHI intensity increased rapidly from the start of the year until it reached a turning point on 25 January when the first confirmed case of coronavirus in Australia was reported [65]. In the following month, more international flights were cancelled, and more restrictions on public gatherings were introduced after the WHO pronounced the COVID-19 a global pandemic [66]. As reflected in Figure 5, there was a constant decline of UHI intensity from January to March, and there were expectations of recording a low UHI intensity during the first lockdown in April and May. However, no significant difference was observed. In fact, drive-through shopping and delivery services became popular during this period and kept the roads busy [67]. The restrictions were temporarily lifted at the end of May, but this only lasted for a month before a second lockdown became imminent again on 8 July [68]. The second lockdown introduced a tougher restriction compared to the first lockdown, and the UHI intensity recorded $1{ }^{\circ} \mathrm{C}$ lower than the past five years' averages. The result during the second lockdown shows a significant difference in the UHI intensity compared to the past five years, which is similar to the study conducted by Earl et al. in 2016, where they showed that the weekly cycle of anthropogenic activity could influence the UHI significantly [69]. This further aligns with the hypothesis made by Simmonds and Keay about the effects of pollutions and anthropogenic heating [70].

Table A6 in Appendix B provides the detailed timeline and restriction conditions of Melbourne lockdowns according to the media release from the Department of Health and Human Services (DHHS) [71].

\subsection{New York City}

The UHI intensity in New York City (NYC) from 2016 to 2020 is illustrated in Figure 6, and it shows a relatively low UHI intensity in 2020, especially after the introduction of the lockdown. The first coronavirus case in the United States was on 11 January, which was relatively earlier than the first case in New York City (NYC) on 1 March. Therefore, the human activities in the first three months might not be distinctive, but the flights and travels between countries and states were already affected before the state of emergency was declared on 13 March [72]. The restrictions placed on human activities included the closure of public schools, bars, and restaurants. The introduction of the PAUSE Program on 27 March required all non-essential workers must stay at home. As the restrictions were not applied until the end of March, there were no significant differences when compared to the previous years. 


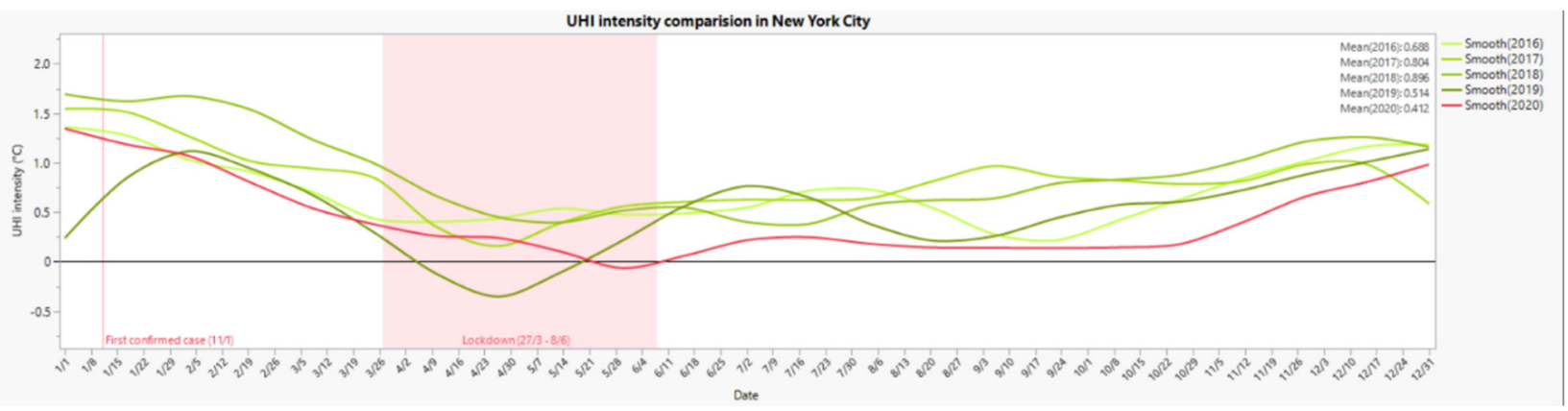

Figure 6. New York City UHI intensity analysis.

It was expected that the UHI intensity in April would be lower than in the past years because a study of the daily and weekly electricity demand in New York City shows a decrease by $16 \%$ on average from late March to April due to COVID-19 restrictions [73]. However, the low UHI intensity was observed in May instead. The stay-at-home order was extended further until June, and NYC began phase 1 and 2 reopening on 8 and 22 June, with more restrictions removed after phase 3 and 4 reopening on 6 and 19 July [74]. The slight increase in UHI intensity from late May to early July was due to the easing of the restriction restrictions. The reopening of the fourth and final phases saw an uptick in COVID cases, resulting in delays to reopen schools and gyms, and remote learning continued to September [74,75]. Therefore, the low UHI intensity in August and September was due to the delayed reopening of public places and other minor restrictions in place after the lockdown period. A brief timeline and restriction conditions of NYS and NYC are summarised in Table A7.

\subsection{Tokyo}

Figure 7 illustrates the UHI intensity in Tokyo from 2016 to 2020. These results reflect the COVID-19 restrictions introduced in Tokyo and Japan. According to the health ministry, the first confirmed case was on 16 January from a man who returned from Wuhan [76]. No restrictions were put in place even after a state of emergency was declared in Hokkaido prefecture on 28 February [77]. Given that the declaration was not nationwide and even the quarantine law was not strict enough to prohibit people's movements [78], human activities in Japan were generally not affected by the coronavirus until March. Typical changes included the cancelation of cherry blossom festivals, adjustment on business hours, and temporarily closing some popular venues [79]. As a result, the UHI intensity pattern did not show a huge difference in the first three months.

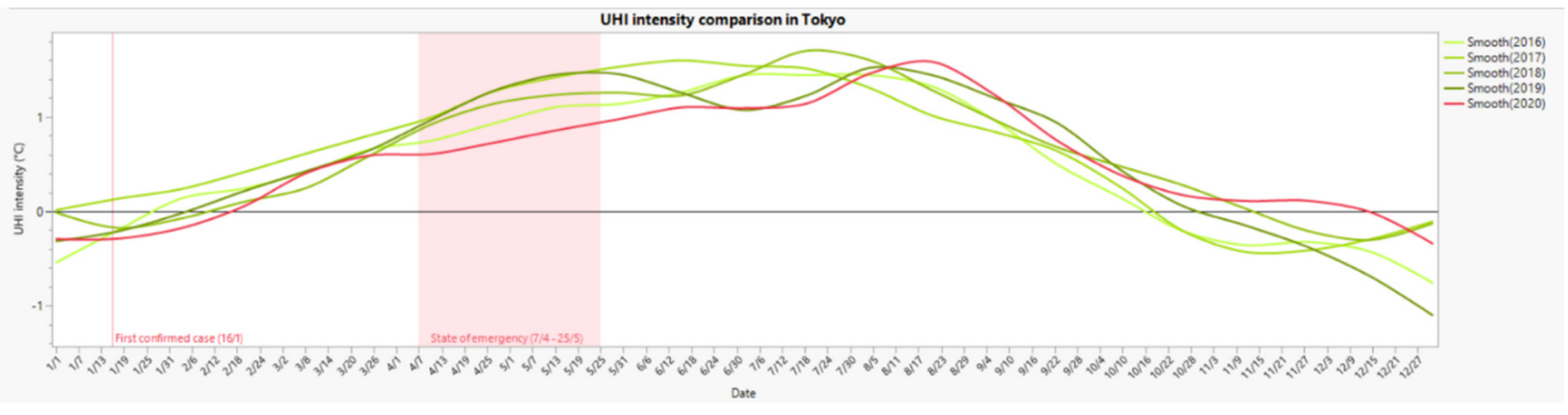

Figure 7. Tokyo UHI intensity analysis.

A brief timeline of Tokyo's COVID-19 outbreak is summarised in Table A8. A state of emergency covering Tokyo and six prefectures was declared by Prime Minster Abe-San on 7th April, and major restrictions were introduced, including banning international travel and the temporary closure of non-essential services. The UHI intensity during the lockdown 
period in April and May was the five-year lowest recorded, with monthly average UHI intensity of $0.5^{\circ} \mathrm{C}$ and $0.8^{\circ} \mathrm{C}$, respectively. The state of emergency remained in place until 25 May, and by 19th June all the businesses were reopened again, and international travels were permitted, and the daily lives of Tokyo citizens were almost back to normal, which explains the increase in UHI intensity after June. On 15 July, the alert level was raised to the highest due to fears of a second wave of the coronavirus despite the government's plan of not declaring the second state of emergency. On 6 August, governor Koike urged the citizens to stay at home and offered compensation funding to some businesses to close early as a means to contain coronavirus $[79,80]$. Since there were no strict lockdown restrictions in place in July and August, the UHI intensity did not show a huge difference compared to the past as people have slowly adapted to living with coronavirus as time went by.

\subsection{Dublin}

Figure 8 illustrates the UHI intensity in Dublin from 2016 to 2020. It shows that the UHI intensity pattern in Dublin was similar to previous years. Table A9 is a summary of Dublin's COVID-19 lockdown situation. The first confirmed case was in the Republic of Ireland on 29th February [81]. Mitigation for the COVID-19 outbreak was put in place on 12 March, education facilities were shut down, and large gatherings were suspended [82]. The government announced the stay-at-home order, which took effect from midnight, 27 March, and extended until 18 May $[83,84]$. During the lockdown period from March to May, Dublin experienced the UCI effect and did not show significant differences when compared to the same period in previous years. As restriction slowly eased in June and July, the UCI effect had turned into the UHI effect, and the UHI intensity during July was the highest in the last five years. With an increase in the number of COVID-19 cases in August, the phased reopening was suspended due to rising concerns of a second lockdown [85]. The UHI intensity equally reached the maximum for the year and kept declining till the end of the year.

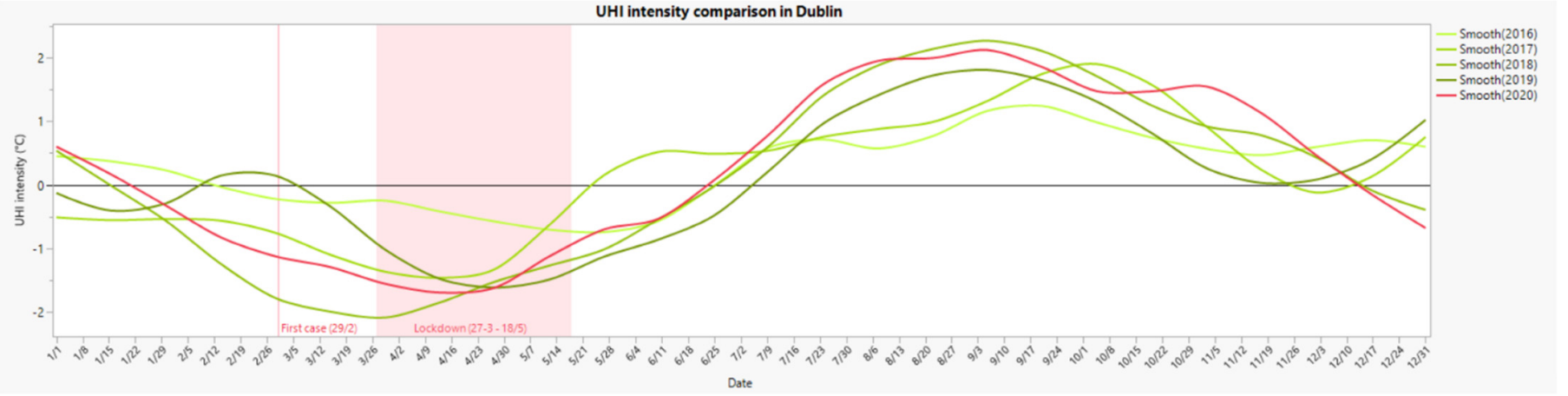

Figure 8. Dublin UHI intensity analysis.

\subsection{Oslo}

The UHI intensity in Oslo from 2016 to 2020 is illustrated in Figure 9; it shows that the UHI intensity of Oslo is relatively high in autumn and winter but close to $0{ }^{\circ} \mathrm{C}$ during spring and summer. The first confirmed case was reported on 26 February [86], and the UHI intensity trend in 2020 did not show a clear correlation to the pandemic events. According to the Norwegian Government Security and Service Organisation (GSSO) records, the government announced a national lockdown on 12 March and introduced internal border control on 16 March. As the authority claimed that it is the strictest policy Norway has, the UHI intensity in March was surprisingly the five-year highest. As the lockdown was extended for few times until 20 April, the UHI intensity remained relatively high. Similar to March, May had the highest UHI intensity, with a slight decline towards June. July and August were the only periods experiencing the UCI effect instead of UHI. The process of reopening was in progress in the following months, after lockdown up until early August. 
However, internal border control was reintroduced on 12 August [87]. The brief timeline of lockdown and restrictions in Oslo is summarised in Table A10.

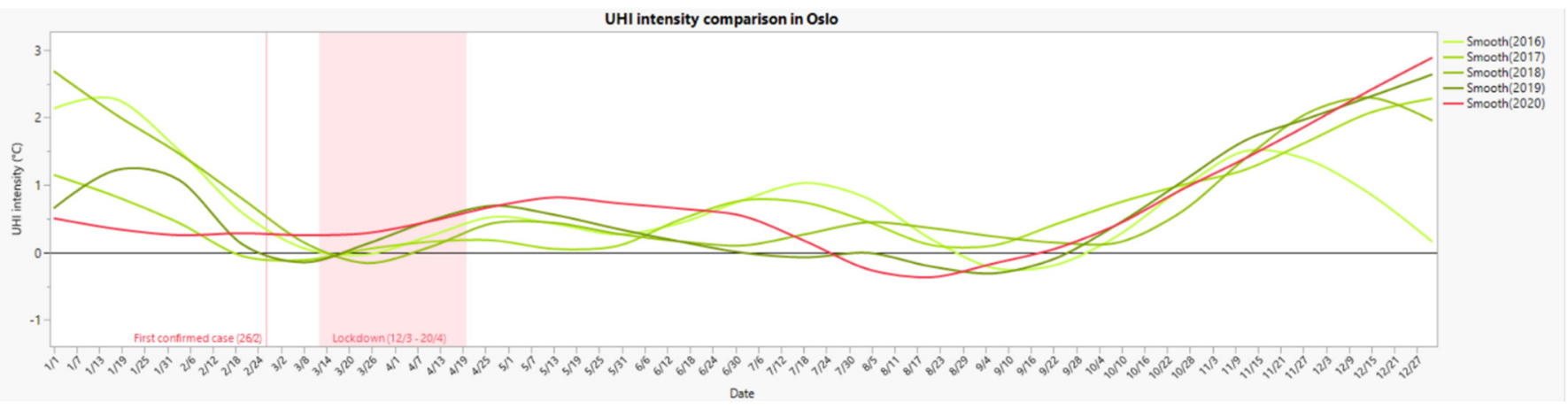

Figure 9. Oslo UHI intensity analysis.

\section{Discussion}

Table 2 is a summary of the annual average UHI intensity of each city over the last five years. It shows that the overall UHI intensity of the selected cities in 2020 has the lowest record when compared to the last 5 years with $\mathrm{UHI}$ intensity of $0.54{ }^{\circ} \mathrm{C}$, while 2017 had the highest UHI intensity of $0.66{ }^{\circ} \mathrm{C}$. The result contradicts the global climate predictions and the recorded global temperature pattern in 2020 [88]. According to the latest Global Climate Report 2021, the average global land and ocean surface temperature for 2020 was $+0.98{ }^{\circ} \mathrm{C}$, which was the second warmest year in the 141-year record [29]. Although UHI intensity does not necessarily represent the actual temperature, this makes it possible to have a low UHI intensity when both urban and rural areas have extremely high temperatures. The trend in UHI intensity in 2020 still shows some abnormal patterns when compared to historical records.

Table 2. Average UHI intensity of the selected cities from January to August.

\begin{tabular}{ccccccc}
\hline \multirow{2}{*}{ Year } & \multicolumn{7}{c}{ Annual Average UHI Intensity $\left({ }^{\circ} \mathbf{C}\right)$} \\
\cline { 2 - 7 } & Melbourne & Tokyo & New York City & Dublin & Oslo & Overall \\
\hline 2016 & 0.99 & 0.53 & 0.68 & 0.25 & 0.69 & 0.63 \\
\hline 2017 & 1.11 & 0.67 & 0.80 & 0.15 & 0.59 & 0.66 \\
\hline 2018 & 0.88 & 0.65 & 0.90 & 0.05 & 0.74 & 0.64 \\
\hline 2019 & 1.03 & 0.61 & 0.52 & 0.09 & 0.59 & 0.57 \\
\hline 2020 & 0.89 & 0.56 & 0.41 & 0.22 & 0.61 & 0.54
\end{tabular}

Note: the year with overall highest UHI intensity is highlighted in red, and the year with lowest overall UHI intensity is hightligted in blue.

As illustrated in Figures 10-12, the daily maximum air temperatures of the urban area in Melbourne, New York City, and Tokyo were relatively low during the lockdown period. Figures 13 and 14 show a slightly different pattern of the daily maximum air temperature of Dublin and Oslo urban area, 2020 had the highest temperature at the start of the year, but this trend changed after the first confirmed case of COVID-19. 
Sustainability 2022, 14, 378

13 of 23

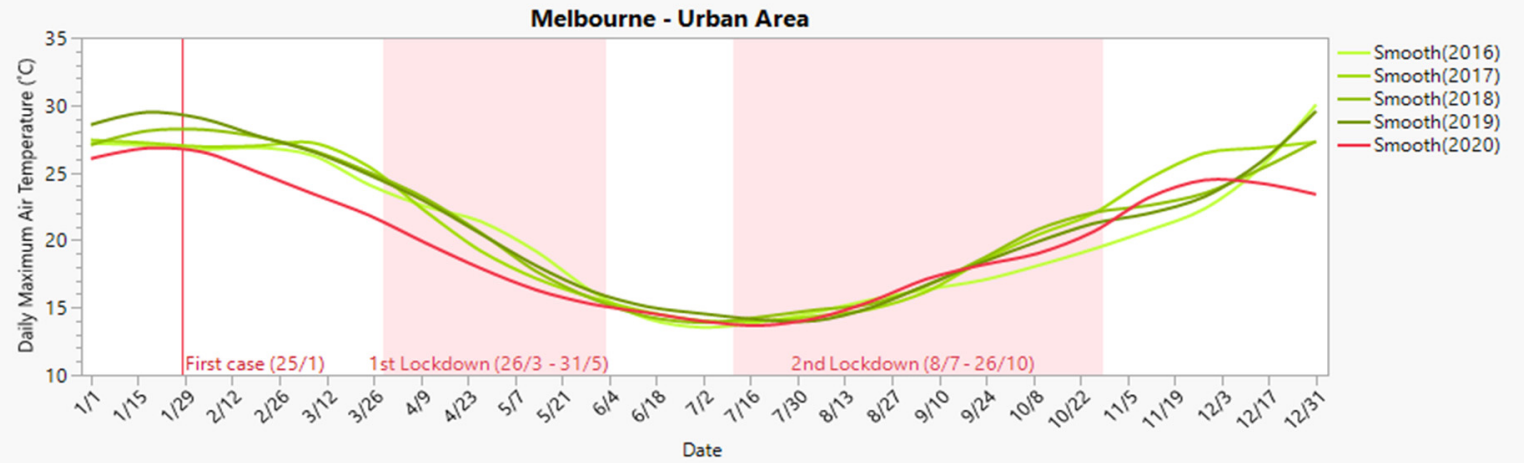

Figure 10. Daily maximum air temperature of Melbourne urban area.

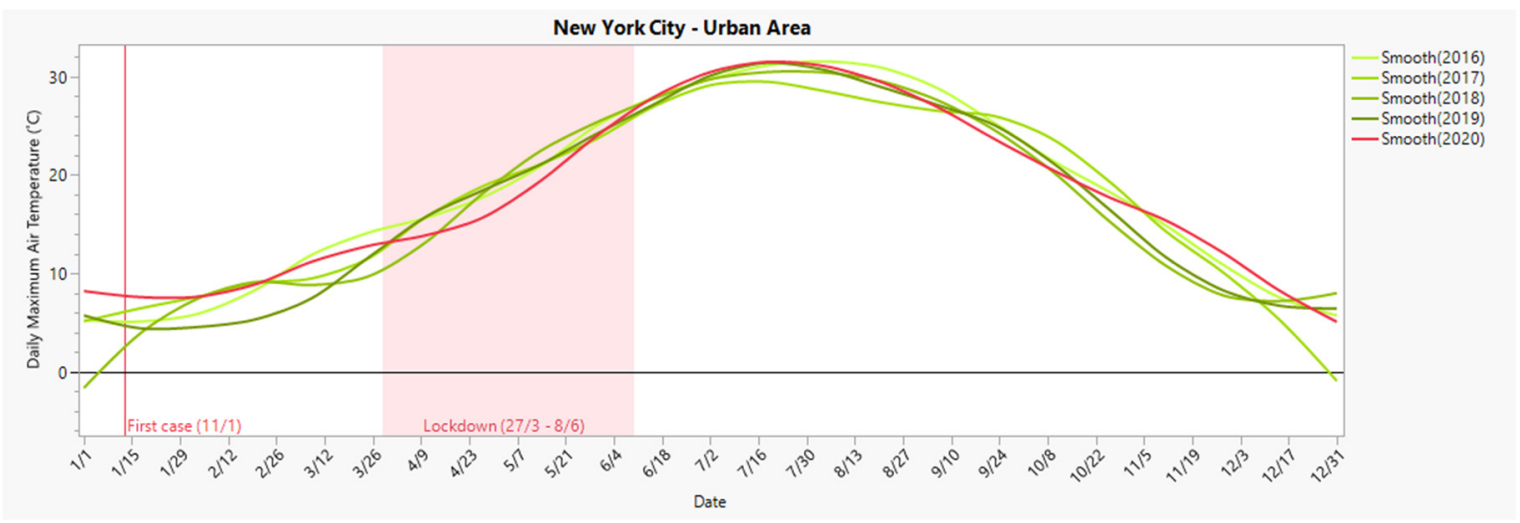

Figure 11. Daily maximum air temperature of New York City urban area.
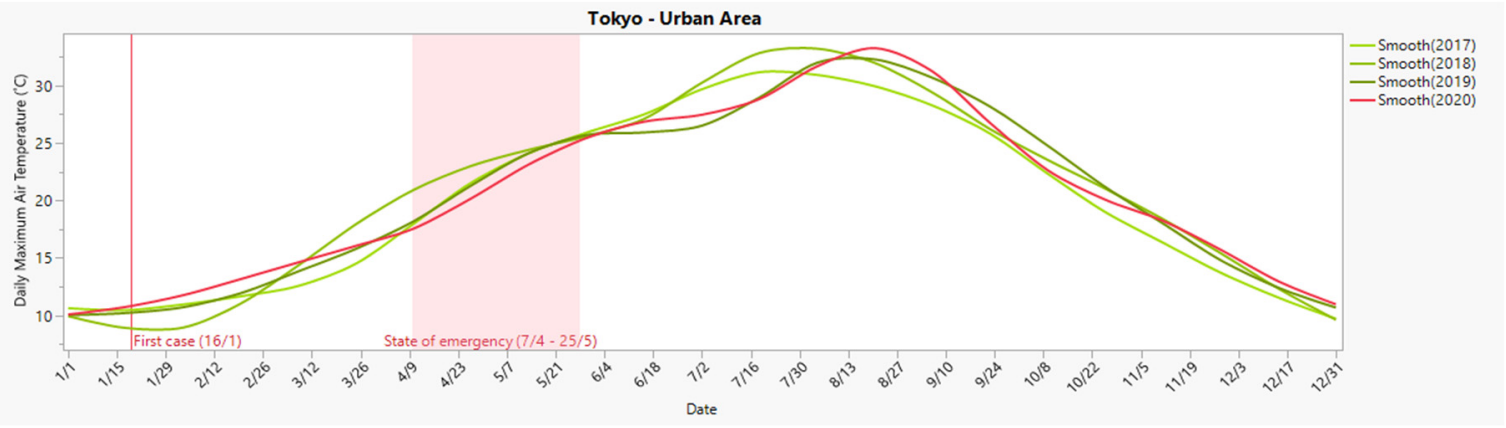

Figure 12. Daily maximum air temperature of Tokyo urban area.

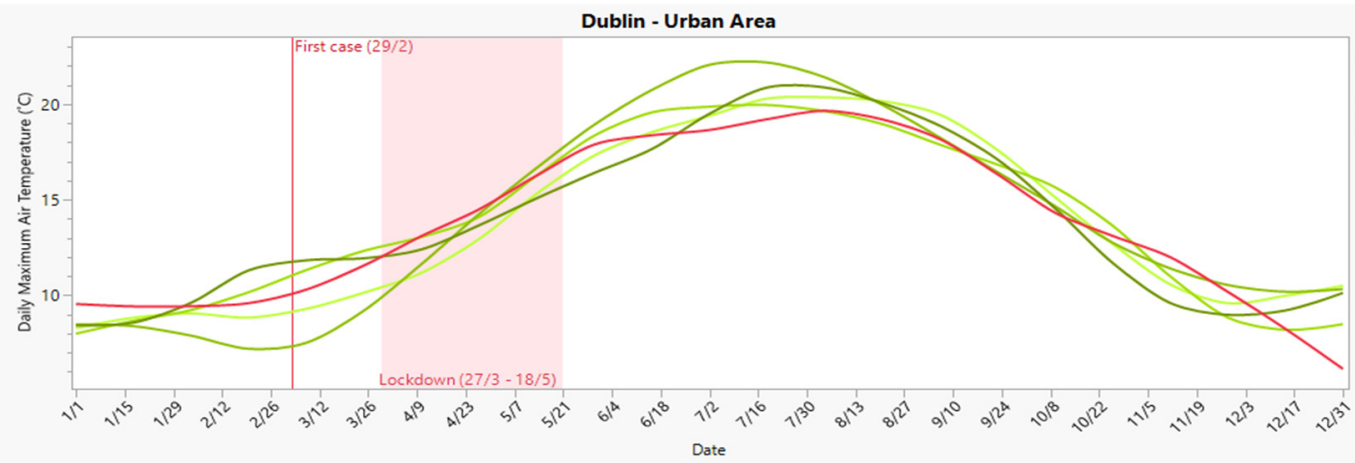

Figure 13. Daily maximum air temperature of Dublin urban area. 


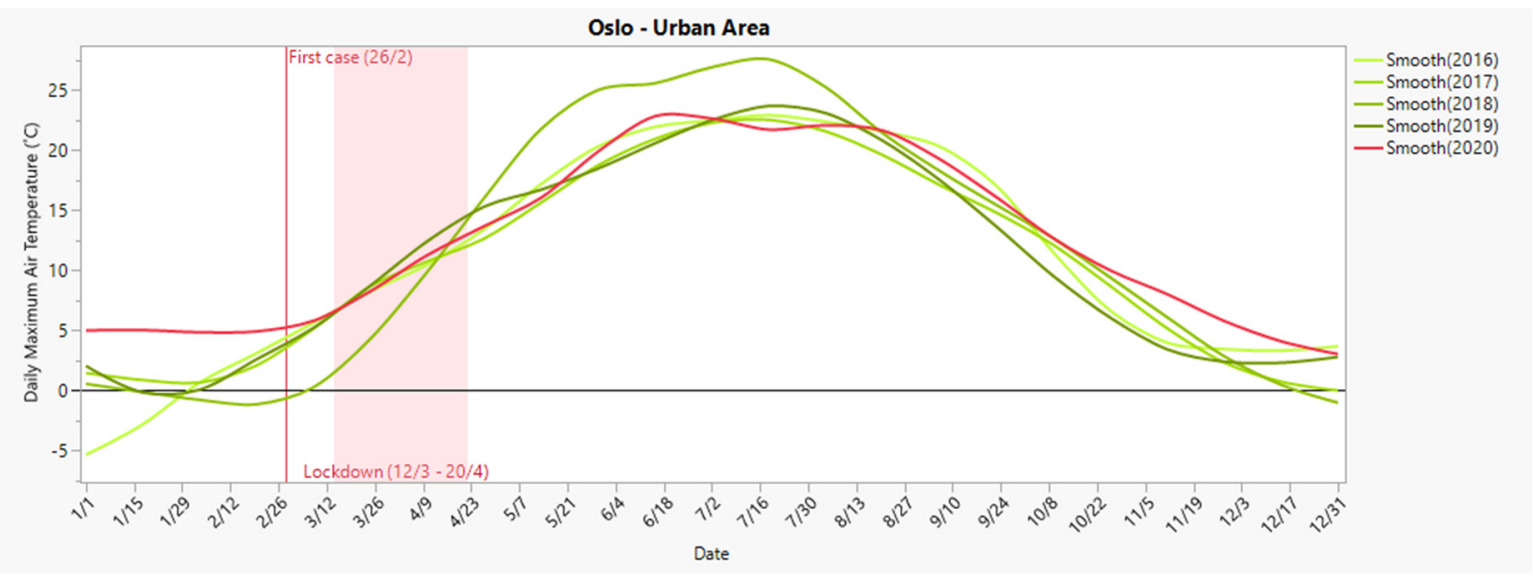

Figure 14. Daily maximum air temperature of Oslo urban area. The curves represented the daily maximum in last 5 years, and the red curve highlights the pattern in 2020. The red shaded regions were the duration of lockdown.

The results show that the UHI intensity pattern in cities with higher population density and urban built-up areas was more affected by the pandemic events. According to the Skyscraper Center ranking, New York City, Tokyo, and Melbourne were listed on the top 20 cities with the most completed structures over $100 \mathrm{~m}$ tall [89]. Both Dublin and Oslo are less urbanised, which were not even on the top 200 list in this ranking system. Therefore, New York City, Tokyo, and Melbourne tend to have higher UHI intensity when compared to Dublin and Oslo.

The figures in Section 4 show the potential of the COVID-19 outbreak to affect UHI to a certain degree.

The following are the key observations from the UHI intensity in 2020:

(1) High-density cities showed a low UHI effect trend after lockdown restrictions were introduced;

(2) The differences in UHI intensity are more distinctive in cities with stricter rules and longer lockdown duration;

(3) The overall UHI intensity in 2020 was the lowest recorded in the past five years.

With respect to all other factors associated with UHI intensity, the COVID-19 situation created a rare condition that impacted the UHI effect due to the absence of human activities, as mentioned in Figure 1. From the results, the human activities factors had a relatively less significant impact on the UHI effect compared to other dominant factors such as climate change or geographical location. Similarly, reports claimed that the carbon emission reduction during COVID-19 was only temporary and will bounce back quickly because the reduction in human movements was not permanent, and the contribution from these factors are considered insignificant on a city scale when compared to the global carbon accumulation $[90,91]$. As the results are not directly reflected on the individual human activity factors, it is impossible to identify which human activities influenced the UHI intensity most.

\section{Recommendations}

Although the COVID-19 lockdown has caused a huge reduction in UHI intensity in some high-density cities, lockdown is not a long-term or sustainable solution to improve the UHI effect. The result has indicated the potential of improving the UHI effect through the mitigatory measures, as shown in Figure 1, thus recommending its implementation by local governments. Driven by the pandemic restriction, there are new opportunities in the areas of energy consumption, transportation, and building materials to mitigate the UHI effect. 


\subsection{Energy Consumption}

During the lockdown, most energy demands were shifted from commercial buildings into residential buildings as more employees were working from home. Since people were spending more time at home instead of at the office, it is easier to motivate people to use energy-efficient home appliances to reduce wasting available energy, thus reducing the cost of electricity bills. The increased use of household energy also encourages individuals to install solar panel systems for their houses to provide cheaper and cleaner off-grid electricity.

The COVID-19 pandemic has also raised awareness on human health and wellbeing, thereby giving a strong reason to demand the government to develop renewable energy projects to replace fossil fuel power plants. These actions will directly reduce GHG emissions in the future and, ultimately, the UHI effect.

\subsection{Transportation}

Owing to the lockdown restrictions, the reduction in vehicles on the roads not only limited human movement and travel distance but also made people rethink the working culture and daily routines. In the future, it will be more acceptable to convince people to conduct works from home if possible instead of traveling miles to their workplaces, and people will be more motivated to use bicycles as a means of transportation based on the increased awareness of health and wellbeing.

In order to achieve the above, some actions are developed by the City of Melbourne and Institute for Sensible Transport [92,93], including:

- Limit car parking space for non-essential vehicles in the inner city to reduce traffic volume into the city and the risks of community spread of the virus in the future;

- Encourage people to use digital tools or apps to monitor and analyse their modes of transportation, thereby allowing them to conduct contact tracing of the coronavirus as well as check their carbon footprint;

- Improve bike lanes and road infrastructures to provide safer and user-friendly road conditions for people to commute by bike.

\subsection{Building Materials}

This study has emphasised the impacts of urban density on the UHI intensity and how building materials play a vital role in defining the urban area and thermal absorption ability of cities. One of the reasons why the UHI intensity in Dublin and Oslo was much lower than other cities in this study is because of more green areas covered by vegetation and fewer concrete-steel-glass high-rise buildings in the urban area. Therefore, the change in building materials can improve the UHI intensity significantly. The following are highlights of the recommendations from the City of Melbourne in the Green Our City Strategic Action Plan on tackling the UHI effect in urban areas [94]:

- Reduce building materials with good solar heat absorption, such as concrete, glass, stainless steel, and ceramic gravel;

- Avoid using dark colors on buildings and road surfaces to reduce radiation absorption;

- Increase the green areas and green infrastructures in the urban area to improve the cooling effect [95].

\subsection{Future Research}

Further research is recommended to investigate the ongoing pandemic events between 2020 and 2021 to have a better perspective on the effects of human movement restrictions towards the UHI intensity. In order to improve the results for future research, land surface temperatures recorded by satellite can help to better analyse the temperature changes on a map. Additionally, real-time monitoring sensors can be deployed to avoid missing data from fixed weather stations by using manual recording methods. Nonetheless, it is more beneficial to investigate further which types of human activities caused the most impacts on UHI to improve the solutions. 


\section{Summary and Conclusions}

In conclusion, this research shows that UHI intensity has reduced during the COVID19 lockdown due to reduced human activities. Although this research was not able to identify which human activities influenced the UHI most, the link between human activities and the UHI effect is clear. As the COVID-19 lockdown is an extreme but temporary measure, the urban temperature is expected to return to a normal level and could also keep increasing after the COVID-19 pandemic. Therefore governments and urban planners around the world should seek to develop sustainable approaches to reduce the UHI effect in the post-pandemic era. Implementing the mitigation measures presented in Figure 1 has a great potential of developing sustainable and resilient cities of the future.

Author Contributions: Conceptualisation, A.W.M.N. and N.M.; methodology, A.W.M.N., N.M., C.Y.W., and P.P.; formal analysis, A.W.M.N., N.M., C.Y.W., and P.P.; data curation, C.Y.W. and P.P.; writing—original draft preparation, C.Y.W. and P.P.; writing—review and editing, A.W.M.N., N.M., C.Y.W., R.C.N., M.A.U.R.T. and P.P.; visualisation, C.Y.W. and P.P.; supervision, A.W.M.N., N.M., M.A.U.R.T.; project administration, A.W.M.N. and N.M.; funding acquisition, A.W.M.N. and N.M. All authors have read and agreed to the published version of the manuscript.

Funding: This research was funded by Victoria University's Planetary Health Grant 2020, grant number PH128.

Institutional Review Board Statement: Not applicable.

Informed Consent Statement: Not applicable.

Data Availability Statement: Not applicable.

Acknowledgments: The authors would like to acknowledge and thank Victoria University for providing the support by a Planetary Health Grant (Grant no. PH128).

Conflicts of Interest: The authors declare no conflict of interest.

\section{Appendix A}

Table A1. Details of weather stations in Melbourne.

\begin{tabular}{|c|c|c|c|c|c|c|}
\hline ID & Name/Location & $\begin{array}{l}\text { Latitude } \\
\text { Decimal }\end{array}$ & $\begin{array}{l}\text { Longitude } \\
\text { Decimal }\end{array}$ & $\begin{array}{l}\text { Elevation } \\
(\mathrm{m})\end{array}$ & $\begin{array}{l}\text { Population Density } \\
\quad\left(\text { People } / \mathrm{km}^{2}\right)\end{array}$ & $\begin{array}{c}\text { Distance Range } \\
(\mathbf{k m})\end{array}$ \\
\hline U1 & Melbourne (Olympic Park) & -37.83 & 144.98 & 7.53 & $5000-10,000$ & $0-25$ \\
\hline $\mathrm{U} 2$ & Viewbank & -37.74 & 145.10 & 66.1 & $1000-2500$ & $0-25$ \\
\hline $\mathrm{U} 3$ & Essendon Airport & -37.73 & 144.91 & 78.4 & $2500-5000$ & $0-25$ \\
\hline $\mathrm{U} 4$ & Melbourne Airport & -37.67 & 144.83 & 113.4 & $250-500$ & $0-25$ \\
\hline U5 & Moorabbin Airport & -37.98 & 145.10 & 12.1 & $1000-2500$ & $0-25$ \\
\hline U6 & Scoresby Research Institute & -37.87 & 145.26 & 80 & $1000-2500$ & $0-25$ \\
\hline U7 & Laverton RAAF & -37.86 & 144.76 & 20.1 & $1000-2500$ & $0-25$ \\
\hline R1 & Sheoaks & -37.91 & 144.13 & 236.7 & $5-10$ & $75-100$ \\
\hline $\mathrm{R} 2$ & Aireys Inlet & -38.46 & 144.09 & 105 & $10-25$ & $>100$ \\
\hline $\mathrm{R} 3$ & Mount Gellibrand & -38.23 & 143.79 & 261 & $5-10$ & $>100$ \\
\hline $\mathrm{R} 4$ & Castlemaine Prison & -37.08 & 144.24 & 330 & $10-25$ & $>100$ \\
\hline $\mathrm{R} 5$ & Redesdale & -37.02 & 144.52 & 290 & $25-50$ & $75-100$ \\
\hline R6 & Lake Eildon & -37.23 & 145.91 & 230 & $1-5$ & $>100$ \\
\hline R7 & Eildon Fire Tower & -37.21 & 145.84 & 637 & $1-5$ & $>100$ \\
\hline $\mathrm{R} 8$ & Nilma North (Warragul) & -38.13 & 145.99 & 134.11 & $10-25$ & $75-100$ \\
\hline R9 & Rhyll & -38.46 & 145.31 & 13.4 & $25-50$ & $75-100$ \\
\hline R10 & Wonthaggi & -38.61 & 145.60 & 51.9 & $25-50$ & $>100$ \\
\hline
\end{tabular}


Table A2. Details of weather stations in New York City.

\begin{tabular}{|c|c|c|c|c|c|c|}
\hline ID & Name/Location & $\begin{array}{l}\text { Latitude } \\
\text { Decimal }\end{array}$ & $\begin{array}{l}\text { Longitude } \\
\text { Decimal }\end{array}$ & $\begin{array}{l}\text { Elevation } \\
\text { (m) }\end{array}$ & $\begin{array}{l}\text { Population Density } \\
\quad\left(\text { People } / \mathrm{km}^{2}\right)\end{array}$ & $\begin{array}{c}\text { Distance Range } \\
(\mathbf{k m})\end{array}$ \\
\hline U1 & Central Park & 40.78 & -73.97 & 47 & $25,000-50,000$ & $0-25$ \\
\hline $\mathrm{U} 2$ & La Guardia Airport & 40.78 & -73.88 & 6 & $5000-10,000$ & $0-25$ \\
\hline $\mathrm{U} 3$ & Teterboro Airport & 40.86 & -74.06 & 2 & $1000-2500$ & $0-25$ \\
\hline $\mathrm{U} 4$ & Harrison & 40.75 & -74.15 & 7 & $5000-10,000$ & $0-25$ \\
\hline U5 & $\begin{array}{c}\text { Newark International } \\
\text { Airport }\end{array}$ & 40.68 & -74.17 & 5 & $1000-2500$ & $0-25$ \\
\hline U6 & JFK International Airport & 40.64 & -73.76 & 3 & $5000-10,000$ & $0-25$ \\
\hline R1 & Shrub Oak & 41.33 & -73.84 & 128 & $100-250$ & $50-75$ \\
\hline $\mathrm{R} 2$ & Port Jervis & 41.39 & -74.69 & 177 & $100-250$ & $75-100$ \\
\hline $\mathrm{R} 3$ & Freehold-Marlboro & 40.31 & -74.25 & 50 & $500-1000$ & $50-75$ \\
\hline $\mathrm{R} 4$ & Wertsville 4 NE & 40.45 & -74.78 & 87 & $100-250$ & $75-100$ \\
\hline $\mathrm{R} 5$ & Flemington 5 NNW & 40.58 & -74.88 & 75 & $100-250$ & $75-100$ \\
\hline R6 & Hightstown $2 \mathrm{~W}$ & 40.27 & -74.57 & 30 & $500-1000$ & $75-100$ \\
\hline R7 & Belvidere Bridge & 40.83 & -75.08 & 78 & $100-250$ & $75-100$ \\
\hline R8 & Baiting Hollow & 40.97 & -72.71 & 24 & $500-1000$ & $>100$ \\
\hline
\end{tabular}

Table A3. Details of weather stations in Tokyo.

\begin{tabular}{|c|c|c|c|c|c|c|}
\hline ID & Name/Location & $\begin{array}{l}\text { Latitude } \\
\text { Decimal }\end{array}$ & $\begin{array}{l}\text { Longitude } \\
\text { Decimal }\end{array}$ & $\begin{array}{l}\text { Elevation } \\
\quad(\mathrm{m})\end{array}$ & $\begin{array}{l}\text { Population Density } \\
\quad\left(\text { People } / \mathbf{k m}^{2}\right)\end{array}$ & $\begin{array}{c}\text { Distance Range } \\
(\mathbf{k m})\end{array}$ \\
\hline U1 & Tokyo (Chiyoda) & 35.68 & 139.75 & 25.2 & $10,000-25,000$ & $0-25$ \\
\hline $\mathrm{U} 2$ & Edogawa Rinkai & 35.63 & 139.85 & 5 & $10,000-25,000$ & $0-25$ \\
\hline $\mathrm{U} 3$ & Nerima & 35.73 & 139.58 & 51 & $10,000-25,000$ & $0-25$ \\
\hline $\mathrm{U} 4$ & Fuchu & 35.68 & 139.48 & 59 & $5000-10,000$ & $0-25$ \\
\hline U5 & Haneda (Airport) & 35.55 & 139.76 & 6 & $10,000-25,000$ & $0-25$ \\
\hline U6 & Saitatma & 35.86 & 139.58 & 8 & $5000-10,000$ & $0-25$ \\
\hline U7 & Koshigawa & 35.88 & 139.75 & 3 & $5000-10,000$ & $0-25$ \\
\hline R1 & Chichibu & 35.98 & 139.06 & 232.1 & $100-250$ & $50-75$ \\
\hline $\mathrm{R} 2$ & Yokoshibahikari & 35.65 & 140.46 & 6 & $250-500$ & $50-75$ \\
\hline R3 & Sakahata & 35.23 & 140.08 & 120 & $250-500$ & $50-75$ \\
\hline R4 & Kamogawa & 35.10 & 140.10 & 5 & $100-250$ & $50-75$ \\
\hline R5 & Tateyama & 34.98 & 139.85 & 5.8 & $250-500$ & $75-100$ \\
\hline R6 & Katori & 35.85 & 140.50 & 37 & $250-500$ & $50-75$ \\
\hline R7 & Katsuura & 35.15 & 140.30 & 11.9 & $100-250$ & 75-100 \\
\hline $\mathrm{R} 8$ & Ogouchi & 35.78 & 139.05 & 530 & $100-250$ & $50-75$ \\
\hline
\end{tabular}

Table A4. Details of weather stations in Dublin.

\begin{tabular}{|c|c|c|c|c|c|c|}
\hline ID & Name/Location & $\begin{array}{l}\text { Latitude } \\
\text { Decimal }\end{array}$ & $\begin{array}{l}\text { Longitude } \\
\text { Decimal }\end{array}$ & $\begin{array}{l}\text { Elevation } \\
\text { (m) }\end{array}$ & $\begin{array}{l}\text { Population Density } \\
\quad\left(\text { People } / \mathrm{km}^{2}\right)\end{array}$ & $\begin{array}{c}\text { Distance Range } \\
(\mathbf{k m})\end{array}$ \\
\hline $\mathrm{U} 1$ & Phoenix Park & 53.36 & -6.32 & 45 & $2500-5000$ & $0-15$ \\
\hline $\mathrm{U} 2$ & Casement Aerodrome & 53.31 & -6.44 & 91 & $1000-2500$ & $0-15$ \\
\hline $\mathrm{U} 3$ & Glasnevin & 53.37 & -6.27 & 20 & $2500-5000$ & $0-15$ \\
\hline $\mathrm{U} 4$ & Merrion Square & 53.34 & -6.25 & 19 & $2500-5000$ & $0-15$ \\
\hline U5 & Dublin Airport & 53.43 & -6.24 & 69 & $500-1000$ & $0-15$ \\
\hline U6 & Dun Laoghaire & 53.29 & -6.13 & 30 & $1000-2500$ & $0-15$ \\
\hline R1 & Kilmichael, Cahore & 52.56 & -6.21 & 30 & $100-250$ & $70-110$ \\
\hline $\mathrm{R} 2$ & Dunoge, Carrickmacross & 53.98 & -6.75 & 78 & $100-250$ & $70-110$ \\
\hline $\mathrm{R} 3$ & Irishstown, Mullingar & 53.54 & -7.36 & 98 & $500-1000$ & $70-110$ \\
\hline $\mathrm{R} 4$ & Gurteen, Tipperary & 53.04 & -8.01 & 75 & $500-1000$ & $70-110$ \\
\hline R5 & Greenshill, Kilkenny & 52.67 & -7.25 & 61 & 500-1000 & $70-110$ \\
\hline
\end{tabular}


Table A5. Details of weather stations in Oslo.

\begin{tabular}{|c|c|c|c|c|c|c|}
\hline ID & Name/Location & $\begin{array}{l}\text { Latitude } \\
\text { Decimal }\end{array}$ & $\begin{array}{l}\text { Longitude } \\
\text { Decimal }\end{array}$ & $\begin{array}{l}\text { Elevation } \\
\quad(\mathrm{m})\end{array}$ & $\begin{array}{l}\text { Population Density } \\
\quad\left(\text { People } / \mathrm{km}^{2}\right)\end{array}$ & $\begin{array}{c}\text { Distance Range } \\
(\mathbf{k m})\end{array}$ \\
\hline U1 & Besserud & 59.96 & 10.67 & 177 & $2500-5000$ & $0-15$ \\
\hline $\mathrm{U} 2$ & Haugenstua & 59.96 & 10.91 & 123 & $2500-5000$ & $0-15$ \\
\hline U3 & Lambertseter & 59.87 & 10.81 & 135 & $2500-5000$ & $0-15$ \\
\hline $\mathrm{U} 4$ & Sofienberg & 59.92 & 10.77 & 37 & $2500-5000$ & $0-15$ \\
\hline U5 & Blindern & 59.94 & 10.72 & 94 & $2500-5000$ & $0-15$ \\
\hline U6 & Disen & 59.94 & 10.79 & 136 & $2500-5000$ & $0-15$ \\
\hline R1 & Nøtterøy-Vestskogen & 59.24 & 10.40 & 25 & $250-500$ & $70-90$ \\
\hline $\mathrm{R} 2$ & Flesberg & 59.86 & 9.45 & 183 & $25-50$ & $70-90$ \\
\hline R3 & Nord-odal & 60.26 & 12.05 & 147 & $25-50$ & $70-90$ \\
\hline $\mathrm{R} 4$ & Nesbyen-Todokk & 60.38 & 9.61 & 166 & $10-25$ & $70-90$ \\
\hline R5 & Sigdal-Nedre Eggedal & 60.14 & 9.44 & 143 & $25-50$ & $70-90$ \\
\hline
\end{tabular}

\section{Appendix B}

Table A6. Timeline of Victoria lockdown and restriction rules under COVID-19 outbreak. (Data source [65-68].)

\begin{tabular}{|c|c|c|c|c|c|c|}
\hline Start & End & $\begin{array}{c}\text { Public } \\
\text { Gathering }\end{array}$ & $\begin{array}{c}\text { Restaurant, Bar \& } \\
\text { Café }\end{array}$ & Shops \& Retails & Curfew & Travel Distance \\
\hline 26 March & 30 March & $\begin{array}{l}\text { Maximum } 10 \\
\text { people }\end{array}$ & Open & Yes & No & No restriction \\
\hline 31 March & 11 May & $\begin{array}{l}\text { Maximum } 2 \\
\text { people }\end{array}$ & Takeaway only & Essential only & No & No restriction \\
\hline 12 May & 31 May & $\begin{array}{l}\text { Maximum } 10 \\
\text { people }\end{array}$ & Takeaway only & Essential only & No & No restriction \\
\hline 1 June & 19 June & $\begin{array}{l}\text { Maximum } 20 \\
\text { people }\end{array}$ & Open with restrictions & Essential only & No & No restriction \\
\hline 20 June & 8 July & $\begin{array}{l}\text { Maximum } 10 \\
\text { people }\end{array}$ & Open with restrictions & Essential only & No & No restriction \\
\hline 8 July & 1 August & $\begin{array}{l}\text { Maximum } 2 \\
\text { people }\end{array}$ & Takeaway only & Essential only & No & $\begin{array}{c}\text { Within reasonable } \\
\text { distance }\end{array}$ \\
\hline 2 August & 13 September & $\begin{array}{l}\text { Maximum } 2 \\
\text { people }\end{array}$ & Takeaway only & $\begin{array}{l}\text { once per day per } \\
\text { household }\end{array}$ & 8 p.m. -5 a.m. & $<5 \mathrm{~km}$ of home \\
\hline 14 September & 29 September & $\begin{array}{l}\text { Maximum } 2 \\
\text { people }\end{array}$ & Takeaway only & $\begin{array}{l}\text { once per day per } \\
\text { household }\end{array}$ & 9 p.m. -5 a.m. & $<5 \mathrm{~km}$ of home \\
\hline 29 September & 26 October & $\begin{array}{l}\text { maximum } 5 \\
\text { people from } 2 \\
\text { households }\end{array}$ & Takeaway only & $\begin{array}{l}\text { once per day per } \\
\text { household }\end{array}$ & 9 p.m. -5 a.m. & $<5 \mathrm{~km}$ of home \\
\hline 27 October & 23 November & $\begin{array}{l}\text { Maximum } 10 \\
\text { people }\end{array}$ & $\begin{array}{c}\text { Predominantly } \\
\text { outdoor with } \\
\text { 10-person group limit }\end{array}$ & Open with restrictions & No & $<25 \mathrm{~km}$ of home \\
\hline
\end{tabular}

Table A7. Brief timeline of New York City lockdown and restriction rules under COVID-19 outbreak.

\begin{tabular}{cc}
\hline Key Dates & Key Announcement \\
\hline 1 March 20 & First COVID-19 case in New York State \\
7 March 20 & NY Governor Andrew Cuomo declares a state of emergency \\
12 March 20 & NYC Mayor Bill de Blasio declares a state of emergency \\
13 March 20 & President Trump declares a national emergency \\
16 March 20 & NYC public schools close \\
17 March 20 & NYC bars and restaurants close, except for delivery \\
22 March 20 & NYS on PAUSE Program begins, all non-essential workers must stay home \\
28 March 20 & Halts all non-essential construction sites in NYS \\
\hline
\end{tabular}


Table A7. Cont.

\begin{tabular}{|c|c|}
\hline Key Dates & Key Announcement \\
\hline 6 April 20 & NYS's stay-at-home order and school closures extends to 29 April \\
\hline 16 April 20 & NYS's stay-at-home order and school closures extends to 15 May \\
\hline 30 April 20 & NYC subway closures from 1 a.m. to 5 a.m. \\
\hline 1 May 20 & Closes all schools for the remainder of the academic year \\
\hline 7 May 20 & Extends PAUSE order to 6 June \\
\hline 14 May 20 & Extends PAUSE order to May 28 for NYC \\
\hline 14 May 20 & State of emergency for NYS extended to 13 June \\
\hline 15 May 20 & Reopen of Drive-in theaters, landscaping, and low-risk recreational activities \\
\hline 23 May 20 & Allows gatherings of up to 10 people with social distancing \\
\hline 8 June 20 & NYC begins Phase 1 reopening \\
\hline 22 June 20 & NYC begins phase 2 of reopening \\
\hline 6 July 20 & NYC begins Phase 3 of reopening, without indoor dining \\
\hline 19 July 20 & NYC begins Phase 4 reopening, excluding malls, museums, and indoor dining/bars \\
\hline 2 September 20 & Gyms in NYC reopen, but indoor group workouts and pools stay closed \\
\hline 9 September 20 & Malls in NYC reopen at $50 \%$ capacity with no indoor dining. Casinos reopen across NYS at $25 \%$ capacity. \\
\hline 29 September 20 & Elementary students return to public school classrooms across NYC \\
\hline 30 September 20 & Indoor dining in NYC resumes with a $25 \%$ occupancy limit \\
\hline
\end{tabular}

Table A8. Brief timeline of the COVID-19 outbreak of Tokyo and Japan as whole country.

\begin{tabular}{|c|c|}
\hline Key Dates & Key Announcement \\
\hline 16 January 20 & First confirmed case in Japan \\
\hline 26 January 20 & Japan started evacuating its citizens from Wuhan, China \\
\hline 10 February 20 & Virus spreading from Diamond Princess Cruise ship arrived in Yokohama Bay \\
\hline 14 February 20 & Kyoto launched its empty tourism campaign \\
\hline 27 February 20 & Prime Minister Abe Shinzo requested closure of all elementary, junior high, and high schools \\
\hline 28 February 20 & Hokkaido prefecture was the first one to declare a state of Emergency \\
\hline 25 March 20 & Tokyo governor Koike-san asked people to stay indoors over the weekend to stop community spread \\
\hline 1 April 20 & Foreigners that have travelled to 73 different countries in the last 14 days will be denied entry to the country. \\
\hline 7 April 20 & Prime Minster Abe Shinzo declare a state of emergency that cover Tokyo and six other prefectures. \\
\hline 10 April 20 & Tokyo government offered financially compensated to businesses that agreed to reduce operating hours \\
\hline 16 April 20 & Japan declared a national wide state of emergency \\
\hline 14 May 20 & The state of emergency lifts from 39 prefectures, but not include Tokyo \\
\hline 25 May 20 & Tokyo has lifted the state of emergency, international travel allowed from permitted countries \\
\hline 27 May 20 & Tokyo ease up restrictions in three stages \\
\hline 1 June 20 & Children allowed back to school \\
\hline
\end{tabular}

Table A9. Brief timeline of Dublin lockdown and restriction rules under COVID-19 outbreak.

\begin{tabular}{|c|c|}
\hline Key Dates & Key Announcement \\
\hline 29 February 20 & First confirmed case in the Republic of Ireland. Ireland entered the containment phase \\
\hline 12 March 20 & Announced the closure of all schools, colleges, and childcare facilities until 29 March \\
\hline 27 March 20 & Announced a national stay-at-home order unit 12 April \\
\hline 10 April 20 & Extended the stay-at-home order unit 5 May \\
\hline 1 May 20 & Extended the stay-at-home order unit 18 May \\
\hline 18 May 20 & Phase one of the government's roadmap of easing COVID-19 restrictions began \\
\hline 8 June 20 & Phase two plus of the government's roadmap of easing COVID-19 restrictions began \\
\hline 29 June 20 & $\begin{array}{r}\text { Phase three began, businesses reopened, including all pubs serving food, cafés, restaurants, hotels, hairdressers, } \\
\text { beauty salons and tourist attractions }\end{array}$ \\
\hline 15 July 20 & $\begin{array}{c}\text { Phase four is postponed to } 10 \text { August; Pubs, hotel bars, nightclubs and casinos will remain closed; Restrictions } \\
\text { on public gathering remained }\end{array}$ \\
\hline 4 August 20 & $\begin{array}{c}\text { Phase four will not proceed on } 10 \text { August; Restaurants and pubs serving food will now have to close by } 11 \mathrm{pm} \\
\text { except deliveries and takeaways }\end{array}$ \\
\hline 7 August 20 & Confirmed cases increased, restrictions were applied to some counties \\
\hline 15 August 20 & Announced of second spread of disease \\
\hline
\end{tabular}


Table A10. Brief timeline of Oslo lockdown and restriction rules under COVID-19 outbreak.

\begin{tabular}{cc}
\hline Key Dates & Key Announcement \\
\hline 26 February 20 & First confirmed case \\
12 March 20 & A national lockdown for 14 days \\
16 March 20 & Introduced an internal border control \\
28 March 20 & The government extended the lockdown until 13 April. \\
14 April 20 & Kindergartens and schools are gradually reopening \\
20 April 20 & Internal border control will be continued unit 16 May \\
30 April 20 & Venues reopened in public places for maximum 50 people; a few community areas are reopening \\
7 May 20 & People allowed back to office and workplace \\
5 June 20 & Gym, water parks, and swimming pools are reopened; venues allowed maximum 200 people \\
15 June 20 & Foreigner works and students allow to entry \\
25 June 20 & Allow travel between Norway and other European countries \\
15 July 20 & Continued internal border control from 14 August for 60 days. \\
7 August 20 & Government infection \\
12 August 20 & More national infection control measurements are being replaced by local measurements. \\
30 September 20 &
\end{tabular}

\section{References}

1. World Health Organization. WHO Announces COVID-19 Outbreak a Pandemic. 12 March 2020. Available online: https: //www.euro.who.int/en/health-topics/health-emergencies/coronavirus-covid-19/news/news/2020/3/who-announcescovid-19-outbreak-a-pandemic (accessed on 10 August 2020).

2. Ducharme, J. World Health Organization Declares COVID-19 A 'Pandemic.' Here's What That Means. TIME. 11 March 2020. Available online: https:/ / time.com/5791661/who-coronavirus-pandemic-declaration/ (accessed on 10 August 2020).

3. World Health Organization. Coronavirus Disease (COVID-19) Pandemic. 21 November 2020. Available online: https://www. who.int/emergencies/diseases/novel-coronavirus-2019 (accessed on 10 August 2020).

4. Rupani, P.F.; Nilashi, M.; Abumalloh, R.A.; Asadi, S.; Samad, S.; Wang, S. Coronavirus pandemic (COVID-19) and its natural environmental impacts. Int. J. Environ. Sci. Technol. 2020, 17, 4655-4666. [CrossRef]

5. Fernando, G. Is Melbourne's Coronavirus Lockdown Really the Longest in the World? Here's How Other Countries Stack Up. SBS News. 8 September 2020. Available online: https://www.sbs.com.au/news/is-melbourne-s-coronavirus-lockdown-reallythe-longest-in-the-world-here-s-how-other-countries-stack-up\#: :text=Melbourne $\%$ E2\%80\%99s\%201ockdown \%20is \%20one\% 20of $\% 20$ the $\%$ 20longest $\% 20$ and,March $\% 2$ C $\%$ which\%20were $\% 20$ initially $\% 20$ extended $\% 20$ to $\% 2011 \% 20$ May (accessed on 4 October 2020)

6. Doman, M.; Scott, N. From Ghost Town to Green Shoots. ABC News. 6 November 2020. Available online: https://www.abc.net. $\mathrm{au} /$ news/2020-11-06/search-melbourne-suburbs-to-see-the-rebound-after-covid-lockdown/12851854?nw=0 (accessed on 25 November 2020).

7. AAEMO. Latest COVID19 Demand Impact Summary. May 2020. Available online: https://www.aemo.com.au/newsroom/ news-updates / latest-covid19-demand-impact-summary (accessed on 25 November 2020).

8. The Bureau of Meteorology and CSIRO. State of the Climate 2020. 2020. Available online: http://www.bom.gov.au/state-of-theclimate/documents/State-of-the-Climate-2020.pdf (accessed on 10 September 2020).

9. Press Trust of India. 17\% Decline in Global Carbon Emssions COVID-19 Lockdown Study. The Economic Times. 20 May 2020. Available online: https:/ / economictimes.indiatimes.com/news/international/business/17-decline-in-global-carbon-emissionsdue-to-covid-19-lockdown-study/articleshow /75840410.cms (accessed on 13 October 2020).

10. Kanniah, K.D.; Zaman, N.A.F.K.; Kaskaoutis, D.G.; Latif, M.T. COVID-19's impact on the atmospheric environment in the Southeast Asia region. Sci. Total Environ. 2020, 736, 139658. [CrossRef] [PubMed]

11. Chowdhuri, I.; Pal, S.C.; Saha, A.; Chakrabortty, R.; Ghosh, M.; Roy, P. Significant decrease of lightning activities during COVID-19 lockdown period over Kolkata megacity in India. Sci. Total Environ. 2020, 747, 141321. [CrossRef] [PubMed]

12. Baldasano, J.M. COVID-19 lockdown effects on air quality by NO2 in the cities of Barcelona and Madrid (Spain). Sci. Total Environ. 2020, 741, 140353. [CrossRef] [PubMed]

13. Rossi, R.; Ceccato, R.; Gastaldi, M. Effect of road traffic on air pollution. Experimental evidence from covid-19 lockdown. Sustainability 2020, 12, 8984. [CrossRef]

14. Barua, S.; Nath, S.D. The impact of COVID-19 on air pollution: Evidence from global data. J. Clean. Prod. 2021, $298,126755$. [CrossRef] [PubMed]

15. Sannigrahi, S.; Kumar, P.; Molter, A.; Zhang, Q.; Basu, B.; Basu, A.S.; Pilla, F. Examining the status of improved air quality in world cities due to COVID-19 led temporary reduction in anthropogenic emissions. Environ. Res. 2021, 196, 110927. [CrossRef] [PubMed] 
16. Toro, R.; Catalán, F.; Urdanivia, F.R.; Rojas, J.P.; Manzano, C.A.; Seguel, R.; Gallardo, L.; Osses, M.; Pantoja, N.; Leiva-Guzman, M.A. Air pollution and COVID-19 lockdown in a large South American city: Santiago Metropolitan Area, Chile. Urban Clim. 2021, 36, 100803. [CrossRef]

17. Girdhar, A.; Kapur, H.; Kumar, V.; Kaur, M.; Singh, D.; Damasevicius, R. Effect of COVID-19 outbreak on urban health and environment. Air Qual. Atmos. Health 2021, 14, 389-397. [CrossRef] [PubMed]

18. Albayati, N.; Waisi, B.; Al-Furaiji, M.; Kadhom, M.; Alalwan, H. Effect of COVID-19 on air quality and pollution in different countries. J. Transp. Health 2021, 21, 101061. [CrossRef]

19. Oke, T.R. The urban energy balance. Prog. Phys. Geogr. Earth Environ. 1988, 12, 471-508. [CrossRef]

20. Oke, T.R. The energetic basis of the urban heat island. Q. J. R. Meteorol. Soc. 1982, 108, 1-24. [CrossRef]

21. Imhoff, M.L.; Zhang, P.; Wolfe, R.E.; Bounoua, L. Remote sensing of the urban heat island effect across biomes in the continental USA. Remote Sens. Environ. 2010, 114, 504-513. [CrossRef]

22. Alahmad, B.; Tomasso, L.P.; Al-Hemoud, A.; James, P.; Koutrakis, P. Spatial Distribution of Land Surface Temperatures in Kuwait: Urban Heat and Cool Islands. Int. J. Environ. Res. Public Health 2020, 17, 2993. [CrossRef]

23. $\mathrm{Wu}, \mathrm{X}$.; Zhang, L.; Zang, S. Examining seasonal effect of urban heat island in a coastal city. PLoS ONE 2019, 14, e0217850. [CrossRef]

24. Morris, C.J.G.; Simmonds, I. Associations between varying magnitudes of the urban heat island and the synoptic climatology in Melbourne, Australia. Int. J. Climatol. 2000, 20, 1931-1954. [CrossRef]

25. Morris, C.J.G.; Simmonds, I.; Plummer, N. Quantification of the influence of wind and cloud on the nocturnal urban heat island of a large city. J. Appl. Meteorol. 2001, 40, 169-182. [CrossRef]

26. Carpio, M.; González, Á.; González, M.; Verichev, K. Influence of pavements on the urban heat island phenomenon: A scientific evolution analysis. Energy Build. 2020, 226, 110379. [CrossRef]

27. Kamboj, S.; Ali, S. Urban sprawl of Kota city: A case study of urban heat island linked with electric consumption. Mater. Today Proc. 2020, 46, 5304-5314. [CrossRef]

28. Yow, D.M. Urban Heat Islands: Observations, Impacts, and Adaptation. Geogr. Compass 2007, 1, 1227-1251. [CrossRef]

29. NOAA National Centers for Environmental Information. State of the Climate Global Climate Report. January 2021. Available online: https:/ / www.ncdc.noaa.gov/sotc/global/202013\#gtemp (accessed on 20 January 2021).

30. Horton, R.M.; Mankin, J.S.; Lesk, C.; Coffel, E.; Raymond, C. A Review of Recent Advances in Research on Extreme Heat Events. Curr. Clim. Chang. Rep. 2016, 2, 242-259. [CrossRef]

31. Smoyer, K.E. Putting risk in its place: Methodological considerations for investigating extreme event health risk. Soc. Sci. Med. 1998, 47, 1809-1824. [CrossRef]

32. Boumans, R.J.M.; Phillips, D.L.; Victery, W.; Fontaine, T.D. Developing a model for effects of climate change on human health and health-environment interactions: Heat stress in Austin, Texas. Urban Clim. 2014, 8, 78-99. [CrossRef]

33. Katsouyanni, K.; Pantazopoulou, A.; Touloumi, G.; Tselepidaki, I.; Moustris, K.; Asimakopoulos, D.; Poulopoulou, G.; Trichopoulos, D. Evidence for Interaction between Air Pollution and High Temperature in the Causation of Excess Mortality. Arch. Environ. Health Int. J. 1993, 48, 235-242. [CrossRef] [PubMed]

34. Hansel, N.N.; McCormack, M.C.; Kim, V. The Effects of Air Pollution and Temperature on COPD. COPD J. Chronic Obstr. Pulm. Dis. 2016, 13, 372-379. [CrossRef] [PubMed]

35. NOAA National Weather Service. Weather Related Fatality and Injury Statistics. 2019. Available online: https://www.weather. gov/hazstat/ (accessed on 5 October 2020).

36. García-Herrera, R.; Díaz, J.; Trigo, R.M.; Luterbacher, J.; Fischer, E.M. A Review of the European Summer Heat Wave of 2003. Crit. Rev. Environ. Sci. Technol. 2010, 40, 267-306. [CrossRef]

37. Bell, J.E.; Brown, C.L.; Conlon, K.; Herring, S.; Kunkel, K.E.; Lawrimore, J.; Luber, G.; Schreck, C.; Smith, A.; Uejio, C. Changes in extreme events and the potential impacts on human health. J. Air Waste Manag. Assoc. 2018, 68, 265-287. [CrossRef] [PubMed]

38. Vitart, F. Monthly forecast and the summer 2003 heat wave over Europe: A case study. Atmos. Sci. Lett. 2005, 6, 112-117. [CrossRef]

39. Salagnac, J.-L. Lessons from the 2003 heat wave: A French perspective. Build. Res. Inf. 2007, 35, 450-457. [CrossRef]

40. Johnson, H.; Kovats, R.S.; McGregor, G.; Stedman, J.; Gibbs, M.; Walton, H.; Cook, L.; Black, E. The impact of the 2003 heat wave on mortality and hospital admissions in England. Health Stat. Q. 2005, 25, 6-11. [CrossRef]

41. Clarke, J.F. Some effects of the urban structure on heat mortality. Environ. Res. 1972, 5, 93-104. [CrossRef]

42. Heaviside, C.; Vardoulakis, S.; Cai, X.-M. Attribution of mortality to the urban heat island during heatwaves in the West Midlands, UK. Environ. Health 2016, 15, S27. [CrossRef] [PubMed]

43. Zhao, L.; Oppenheimer, M.; Zhu, Q.; Baldwin, J.; Ebi, K.L.; Bou-Zeid, E.; Guan, K.; Liu, X. Interactions between urban heat islands and heat waves. Environ. Res. Lett. 2018, 13, 034003. [CrossRef]

44. Vaidyanathan, A.; Malilay, J.; Schramm, P.; Saha, S. Heat-Related Deaths-United States, 2004-2018. MMWR Morb. Mortal. Wkly. Rep. 2020, 69, 729-734. [CrossRef] [PubMed]

45. Cleugh, H.; Smith, M.S.; Battaglia, M.; Graham, P. Climate Change: Science and Solutions for Australia; CSIRO: Canberra, Australia, 2011. 
46. He, J.; Chen, G.; Jiang, Y.; Jin, R.; Shortridge, A.; Agusti, S.; He, M.; Wu, J.; Duarte, C.M.; Christakos, G. Comparative infection modeling and control of COVID-19 transmission patterns in China, South Korea, Italy and Iran. Sci. Total Environ. 2020, 747, 141447. [CrossRef]

47. Yang, L.; Qian, F.; Song, D.-X.; Zheng, K.-J. Research on Urban Heat-Island Effect. Procedia Eng. 2016, 169, 11-18. [CrossRef]

48. Stewart, I.D.; Oke, T.R. Local Climate Zones for Urban Temperature Studies. Bull. Am. Meteorol. Soc. 2012, 93, 1879-1900. [CrossRef]

49. Schatz, J.; Kucharik, C.J. Urban climate effects on extreme temperatures in Madison, Wisconsin, USA. Environ. Res. Lett. 2015, 10, 094024. [CrossRef]

50. Yang, X.; Li, Y.; Luo, Z.; Chan, P.W. The urban cool island phenomenon in a high-rise high-density city and its mechanisms. Int. J. Climatol. 2017, 37, 890-904. [CrossRef]

51. United States Environmental Protection Agency, Heat Island Effect. 2020. Available online: https://www.epa.gov/heatislands (accessed on 24 July 2020).

52. Zhou, B.; Rybski, D.; Kropp, J.P. On the statistics of urban heat island intensity. Geophys. Res. Lett. 2013, 40, 5486-5491. [CrossRef]

53. U.S. Census Bureau. Urban and Rural. 2020. Available online: https://www.census.gov/programs-surveys/geography/ guidance/geo-areas/urban-rural.html (accessed on 1 September 2020).

54. Bureau of Meteorology. Climate Data Online. 2020. Available online: http://www.bom.gov.au/climate/data/index.shtml? bookmark=136\&zoom=3\&lat=-37.1235\&lon=145.2\&layers=B00000TFFFFFFFTFFFFFFFFFFFFFFFFFFFFTTT\&dp=IDC10002- $d(a c-$ cessed on 11 August 2020).

55. Norwegian Climate Service Center. Observations and Weather Statistics. 2020. Available online: https://klimaservicesenter.no/ observations / (accessed on 12 September 2020).

56. Met Éireann Forecast. The Irish Meteorological Service. 2020. Available online: https://www.met.ie/ (accessed on 25 September 2020).

57. National Weather Service. NOWData-NOAA Online Weather Data. 2020. Available online: https://w2.weather.gov/climate/ xmacis.php? wfo=okx (accessed on 2 August 2020).

58. Japan Meterological Agency. Historical Weather Data Search. 2020. Available online: https://www.data.jma.go.jp/obd/stats/ etrn/index.php (accessed on 1 August 2020).

59. City Population. Map Index. 2020. Available online: https://www.citypopulation.de/mapindex.html (accessed on 23 October 2020).

60. Central Statistics Office. 2020. Available online: https://www.cso.ie/en/ (accessed on 12 October 2020).

61. Statistics Norway. Statistisk Sentralbyrå. 2020. Available online: https://www.ssb.no/en (accessed on 26 September 2020).

62. National Statistics Center. e-State: Statistics of Japan. 2020. Available online: https://www.e-stat.go.jp/en (accessed on 26 September 2020).

63. Australian Bureau of Statistics. Data by Region. 2020. Available online: https://itt.abs.gov.au/itt/r.jsp?databyregion (accessed on 26 October 2020).

64. United States Census Bureau. QuickFacts: New York City, New York. 2020. Available online: https://www.census.gov/ quickfacts/fact/table/newyorkcitynewyork/PST045219 (accessed on 15 November 2020).

65. Handley, E. From Wuhan to Australia: A Timeline of Key Events in the Spread of the Deadly Coronavirus. ABC News. 6 April 2020. Available online: https:/ / www.abc.net.au/news/2020-01-29/coronavirus-timeline-from-wuhan-china-to-global-crisis / 11903298 ? nw $=0$ (accessed on 13 July 2020).

66. 9 News Staff. Timeline: How Coronavirus Spread from China to Australia. Nine Digital. 29 April 2020. Available online: https:/ / www.9news.com.au/national/coronavirus-time-of-how-covid19-spread-from-china-to-australia/b73efd0a-fb3 8-44a2-9d34-e68f1de5098e (accessed on 13 July 2020).

67. McNaughton, J. COVID-19 Restrictions Sees Drive-Through Businesses Boom as Customers Avoid Supermarkets, Keep Their Distance. ABC News. 26 April 2020. Available online: https://www.abc.net.au/news/2020-04-26/coronavirus-drive-throughbusiness-boom/12184972 (accessed on 13 July 2020).

68. Vaughan, R.; Ky, J. A Timeline of How Melbourne Landed Back in Stage three Lockdowns. 7 News. 11 July 2020. Available online: https:/ /7news.com.au/lifestyle/health-wellbeing/a-timeline-of-how-melbourne-landed-back-in-stage-three-lockdowns-c1157684\#: :text=\%20A\%20timeline \%20of\%20how\%20Melbourne \%20landed\%20back,for \%20the\%20first $\% 20$ time $\% 20$ in $\% 20$ a... \%20More\%20 (accessed on 3 August 2020).

69. Earl, N.; Simmonds, I.; Tapper, N. Weekly cycles in peak time temperatures and urban heat island intensity. Environ. Res. Lett. 2016, 11, 074003. [CrossRef]

70. Simmonds, I.; Kaval, J. Day-of-the week variation of rainfall and maximum temperature in Melbourne, Australia. Arch. Meteorol. Geophys. Bioclimatol. Ser. B 1986, 36, 317-330. [CrossRef]

71. Department of Health and Human Services. Coronavirus (COVID-19). Available online: https://www.dhhs.vic.gov.au/ coronavirus (accessed on 22 August 2020).

72. Lapin, T. Coronavirus in NY: A Timeline of How the Disease Spread through the Metro Area. New York Post. 12 March 2020. Available online: https:/ / nypost.com/2020/03/12/coronavirus-in-ny-a-timeline-of-how-the-disease-spread-throughthe-metro-area / (accessed on 26 June 2020). 
73. Lee, A.; DeVibiss, J. Daily Electricity Demand in New York Falls about 13\% after COVID-19 Mitigation Efforts, Washington, DC. May 2020. Available online: https:/ / www.eia.gov/todayinenergy/detail.php?id=43635\#tab1 (accessed on 12 October 2020).

74. Kerr, A. A Historical Timeline of COVID-19 in New York City. Investopedia. 6 October 2020. Available online: https://www. investopedia.com/historical-timeline-of-covid-19-in-new-york-city-5071986 (accessed on 10 November 2020).

75. Vazquez, J.; Shea, T.; Rajamani, M.; Price, B.; Intarasuwan, K. Timeline: Tracking the Spread of COVID-19 in Tri-State. NBC Universal Media. 25 November 2020. Available online: https://www.nbcnewyork.com/news/local/timeline-tracking-thespread-of-covid-19-in-tri-state/2313123/ (accessed on 2 October 2020).

76. Kyodo. Japan Confirms First Case of Coronavirus that Has Infected Dozens in China. The Japan Times. 16 January 2020. Available online: https:/ / www.japantimes.co.jp/news/2020/01/16/national/science-health/japan-first-coronavirus-case/ (accessed on 13 July 2020).

77. Kyodo News. Hokkaido Declares State of Emergency over Coronavirus. KYODO NEWS. 28 February 2020. Available online: https://english.kyodonews.net/news/2020/02/69d1b85128b9-urgent-hokkaido-declares-state-of-emergency-overcoronavirus.html (accessed on 20 August 2020).

78. Osumi, M. Japan Tightens Border Controls over COVID-19, But Power to Quarantine Limited. The Japan Times. 9 March 2020. Available online: https:/ /www.japantimes.co.jp/news/2020/03/09/national/japan-border-controls-coronavirus / (accessed on 20 August 2020).

79. Furutani, K. Live updates: The Covid-19 Coronavirus Situation in Tokyo and Japan Right Now. Time Out Tokyo. 20 August 2020. Available online: https://www.timeout.com/tokyo/things-to-do/live-updates-the-covid-19-coronavirus-situation-in-tokyoand-japan-right-now (accessed on 20 August 2020).

80. Tokyo Metropolitan Government. Updates on COVID-19 in Tokyo. Tokyo Metropolitan Governmen. 20 August 2020. Available online: https:/ / stopcovid19.metro.tokyo.lg.jp/en/ (accessed on 20 August 2020).

81. Coronavirus: First case confirmed in Republic of Ireland. BBC News. 29 February 2020. Available online: https://www.bbc.com/ news / world-europe-51693259 (accessed on 6 September 2020).

82. Leahy, P.; Cullen, P.; Lynch, S.; Kelly, F. Coronavirus: Schools, Colleges and Childcare Facilities in Ireland to Shut. The Irsish Times. 12 March 2020. Available online: https://www.irishtimes.com/news/health/coronavirus-schools-colleges-and-childcarefacilities-in-ireland-to-shut-1.4200977 (accessed on 6 September 2020).

83. Carroll, R. 'Stay home': Varadkar Announces Sweeping Two-Week Lockdown. The Guardian. 28 March 2020. Available online: https://www.theguardian.com/world/2020/mar/27/stay-home-varadkar-urges-irish-in-drastic-lockdown (accessed on 6 September 2020).

84. Kenny, A. Outdoor Time for over 70s and Exercise Limit Extended to $5 \mathrm{~km}$. RTÉ News. 1 May 2020. Available online: https://www.rte.ie/news/2020/0501/1135923-cabinet/ (accessed on 6 September 2020).

85. BBC News. Coronavirus: Concern over 'Increasing Number' of Cases in NI. BBC News. 11 August 2020. Available online: https://www.bbc.com/news/uk-northern-ireland-53740465 (accessed on 7 September 2020).

86. AFP. Updated: Norway Announces First Case of Coronavirus. The Local Norway. 27 February 2020. Available online: https: / / www.thelocal.no/20200226/breaking-norway-announces-first-case-of-coronavirus (accessed on 5 October 2020).

87. Norwegian Government Security and Service Organisation. Timeline: News from Norwegian Ministries about the Coronavirus disease Covid-19. Government.no. 27 February 2020. Available online: https://www.regjeringen.no/en/topics/koronaviruscovid-19/timeline-for-news-from-norwegian-ministries-about-the-coronavirus-disease-covid-19/id2692402/ (accessed on 2 November 2020).

88. NOAA National Centers for Environmental Information. State of the Climate: Global Climate Report. July 2020. Available online: https://www.ncdc.noaa.gov/sotc/global/202007/supplemental/page-1 (accessed on 26 November 2020).

89. The Skyscraper Center. Cities Ranked by Number of Completed Structures (Buildings \& Towers). 2020. Available online: http:/ / skyscrapercenter.info/ cities?list=structures (accessed on 26 November 2020).

90. Baj, L. COVID-19 Had 'No Measurable Impact' on Carbon Emissions, so There's Not Even A Silver Lining. Pedestrian. 24 November 2020. Available online: https:/ / www.pedestrian.tv/news/covid-19-carbon-emissions/ (accessed on 1 December 2020).

91. Ryan, J. COVID-19 Lockdowns Caused an 'Extreme' Reduction in Carbon Emissions. Cnet. 19 May 2020. Available online: https: //www.cnet.com/news/covid-19-lockdowns-caused-an-extreme-reduction-in-carbon-emissions/ (accessed on 4 October 2020).

92. City of Melbourne. Transport Strategy 2030, Melbourne. 2020. Available online: https://www.melbourne.vic.gov.au/ SiteCollectionDocuments/transport-strategy-2030-city-of-melbourne.pdf (accessed on 23 November 2020).

93. Institute for Sensible Transport. Institute for Sensible Transport Projects. 2020. Available online: https://sensibletransport.org. au/projects/ (accessed on 1 December 2020).

94. City of Melbourne. Green Our City Strategic Action Plan 2017-2021. June 2017. Available online: https:/ /www.melbourne.vic gov.au/sitecollectiondocuments / green-our-city-action-plan-2018.pdf (accessed on 15 November 2020).

95. Cohen, P.; Potchter, O.; Matzarakis, A. Daily and seasonal climatic conditions of green urban open spaces in the Mediterranean climate and their impact on human comfort. Build. Environ. 2012, 51, 285-295. [CrossRef] 